\title{
Preliminary Research about Producers' Perceptions of Relationship Quality with Retailers in the Supply Chain of Organic Food Products in Croatia
}

\author{
Dušanka Gajdić $1,2, *$, Željka Mesić ${ }^{3}$ and Kristina Petljak ${ }^{4}$ \\ 1 Department of Agricultural Management, Križevci College of Agriculture, 48260 Križevci, Croatia \\ 2 Faculty of Economics and Business, University of Rijeka, 51000 Rijeka, Croatia \\ 3 Department of Marketing in Agriculture, Faculty of Agriculture, University of Zagreb, 10000 Zagreb, Croatia; \\ zmesic@agr.hr \\ 4 Department of Trade and International Business, Faculty of Economics and Business, University of Zagreb, \\ 10000 Zagreb, Croatia; kpetljak@efzg.hr \\ * Correspondence: dgajdic@vguk.hr
}

Citation: Gajdić, D.; Mesić, Ž.; Petljak, K. Preliminary Research about Producers' Perceptions of Relationship Quality with Retailers in the Supply Chain of Organic Food Products in Croatia. Sustainability 2021, 13, 13673. https://doi.org/ $10.3390 /$ su132413673

Academic Editor: Luigi Roselli

Received: 19 October 2021

Accepted: 6 December 2021

Published: 10 December 2021

Publisher's Note: MDPI stays neutral with regard to jurisdictional claims in published maps and institutional affiliations.

Copyright: (c) 2021 by the authors. Licensee MDPI, Basel, Switzerland. This article is an open access article distributed under the terms and conditions of the Creative Commons Attribution (CC BY) license (https:// creativecommons.org/licenses/by/ $4.0 /)$.

\begin{abstract}
Due to insufficient research on the relationships in the supply chain (SC) of agri-food products, and especially organic food products, the main goal of this study was to examine the perceptions of organic food producers about the importance of collaboration and trust to their performance in the organic food SC. An analysis of previous research has concluded that the important categories of relationship quality $(\mathrm{RQ})$ are the following: appropriate inter-organisational collaboration, effective communication, mutual exchange of information, resource sharing (physical, financial, human, and organisational), willingness to share risks, transparency between partners, relationship quality and commitment, and the presence of trust between partners in the SC. An empirical study based on in-depth interviews was conducted on a sample of six organic food producers in Croatia. The results indicated that the producers' perceptions of the impact of collaboration and trust on overall performance differs depending on the length of the collaboration with retailers, the types of products, and the percentage of overall sales they sell through retailers. The results of this research can serve as an information base for all stakeholders in the SCs of organic products by encouraging them to participate in activities that will strengthen trust and collaboration as a prerequisite for increasing SC organic food performance.
\end{abstract}

Keywords: relationship quality; organic food producers; organic food SC; qualitative research; Croatia

\section{Introduction}

In the last ten years, both in the world and in Croatia, there has been an increased interest in organic production, and this is the result of several factors. The most important of these are [1]: the large area of uncultivated land suitable for organic production, low pollution of the ecological system, increased consumer concern for health, and the growing importance of renewable sources in the global environment.

At the global and European level, there is a growing trend of areas under organic production. Since 2000, there has been an increase in areas under organic production of greater than 500\%. According to the FiBL survey [2], there has been a steady increase in the area covered by organic production in the world, which has grown to 71.5 million hectares. Organic agriculture is developing rapidly, and available statistics show that organic farming is practiced by 2.8 million producers in 186 countries [2].

Although the interest in organic agriculture is growing, there is limited research focused on organic food producers [3-6]. Small organic food producers are often very inefficient, and they are interested in different possibilities within distribution channels, such as networking and better collaboration within the SC. 
Agri-food supply chains (AFSCs) differ significantly from other SCs due to the specifics of agricultural production, its dependence on natural conditions, the seasonal nature of production, specific product characteristics (e.g., short shelf life and perishability of products), etc. The authors of [7,8] state that AFSCs are characterized by: (1) business relationships that typically confront profit sharing within the SC (the so-called profit-rebate relationship); (2) treatment of farmers as substitutable (and usable) input suppliers, who often operate in a limited market or under short-term contracts and therefore assume greater risk; and (3) profits from the sale of finished food products that are unevenly distributed along the SC because processors and retailers usually earn a significantly higher share compared to organic food producers.

Dani [9] points out that the AFSC has two main goals: (1) to meet consumer demands and (2) to manage the chain effectively and become and remain economically viable. In addition, Dani [9] believes that the AFSC can be discussed in two ways, as: (1) processororiented commodity chains and as (2) consumer-oriented value chains. The quality and safety of agri-food products are just some of the aspects that consumers care about more today than before, and which are also necessary prerequisites especially for AFSCs [10].

Sustainable food production and distribution is one of the most important problems in developed and developing countries. Market regulation, the emergence of global companies, and changing patterns of consumer behaviour when buying and consuming food (e.g., demand for off-season products) are just some of the factors that significantly affect AFSCs. The agri-food activity also has a direct impact on the environment, playing a very important role in the sustainable management of natural resources and in the adaptation and mitigation of the effects of climate change [11]. Food supply chains (FSCs) from the primary farmer to the final consumer create a direct impact on the environment through the way food is produced, processed, transported, stored, and prepared, generating significant amounts of food waste and food losses. AFSCs need to become not only efficient and affordable, but also more sustainable and resilient. The long-term sustainability of this system requires the joint and integrated collaboration of all stakeholders in the FSC to include economic, technological, organisational, social, and environmental aspects in the strategic planning and design of sustainable AFSCs.

According to the definition given by Seuring and Müller [12], sustainable supply chain management (SSCM) can be defined as 'management of material, information, and capital flows as well as collaboration between companies along the SC, while achieving objectives from all levels of sustainable development, i.e., economic, environmental, and social'.

One of the most frequently cited definitions of sustainability is the triple bottom line (TBL) model, introduced by Elkington [13], which divides sustainability into three basic points: (a) economic prosperity; (b) environmental quality; and (c) social equality. All three basic points and their interactions must be considered when designing sustainable AFSCs. The economic, environmental, and social requirements of stakeholders in the SSCM of agri-food products depend on the quality of collaboration and involve individual stakeholders in SSCM projects, e.g., retailers often play a central role in FSCs by linking primary production and processing with consumers [14] and dictate market conditions that include elements of sustainability (such as quality standards, environmental management systems, etc.).

According to Dania et al. [15], 10 key behavioural factors have been identified that enable an effective collaboration system for sustainable AFSCM, namely: joint efforts, division of activities, value of collaboration, adjustment, trust, commitment, fair distribution of power, continuous improvement, coordination, and stability.

Indicators of how the current characteristics of the agri-food system should change were presented by Ambler-Edwards et al. [16], citing some of the new sustainability requirements for all actors in AFSC at the following levels, including quality of SC relationships. This includes better horizontal collaborative relationships, better vertical collaboration, long-term supply contracts in which power is balanced, partnerships with 
other sectors/industries, and connecting the entire chain from the farm to the consumer while collaborating with all stakeholders of the chain.

A case study on the Parmigiano Reggiano cheese SC presented the results of in-depth research where the role of the $\mathrm{SC}$, deriving by cooperation, is relevant to increase the sustainability and resilience of the production chain and of the entire eco-social local system, even in economically fragile areas [17].

In essence, collaboration is a key approach to achieve a balance between all sustainability goals, by mitigating the individualistic and opportunistic behaviour of stakeholders in the SC. Effective and quality collaboration for sustainable AFSCs can make it easier for farmers to access resources, opportunities, and benefits equal to those of the other stakeholders in the SC $[15,18,19]$.

Precisely because of the above, AFSCs should be viewed as 'value chain systems' in which the raw material (from an agro-industrial source) is converted into final consumption as it moves through the chain and increases in value. AFSC members strive to improve the functioning of the chain, from the perspective of quality, competitiveness, pricing, requirements for the absolute safety of agri-food products, and regarding mutual relations between chain members (trust, communication, knowledge exchange, loyalty, etc.).

Despite the need to increase the efficiency of the distribution of organic food products in Croatia, so far, no research has been identified in international and domestic literature that has researched the quality of the relationship between producers and retailers in the organic food sector. The only research in Croatia that has dealt with the perceptions of producers about the impact of the quality of relations on the performance of SCs is that of Mesić et al. [20] carried out for the SC performance of the traditional food sector. In this paper, the key problems identified are the use of unfair trading practices (exploitative contracts, high rebates), receivables, non-compliance with payment deadlines, low wholesale prices, high costs of logistics, and poor collaboration and integration between chain members. A similar situation is still present in many countries of central and eastern Europe [21]. Considering the growth of the importance of the organic food sector in the world and in Croatia, the objective of this paper is to examine the perceptions of organic food producers about the importance of collaboration and trust on their performance in the organic food SC, and to give recommendations for the improvement of relationship quality $(\mathrm{RQ})$ with retailer within this SC.

Empirical research will be used to answer the following research questions: 'How do organic food producers perceive the most important factors of collaboration with retailers in the organic food SC?'; 'How developed is trust among organic food producers and retailers in the organic food SC?'; and 'How do collaboration and trust between organic food producers and retailers influence overall organic food SC performance?'

The remainder of the paper is structured as follows: The next section addresses relationship quality and collaboration in the AFSC, trust, and overall supply chain performance, followed by a short description of the organic food market and main distribution channels, with a special focus on the Croatian market. Thereafter, the main findings of the qualitative empirical research conducted on a sample of organic food producers in Croatia are discussed, followed by a discussion of the research results. The paper concludes with a section on the managerial implications, limitations, and future research directions.

\section{Literature Review}

One of the goals of the SC is that companies do not view each other individually, but as members of a competitive network in which multiple companies are involved in value creation [22]. This goal can only be achieved through the collaboration of all members in the SC, because the network has a competitive environment that brings benefits to all stakeholders and strengthens the SC [23]. Collaboration is a process in which several people or business entities come together (integrate) to perform a job or activity, sharing tasks and roles, helping each other, and coordinating efforts, to achieve a common goal. This implies collaboration that includes partnership, joint leadership, risk sharing, co-decision 
(i.e., a closer and more intensive relationship), equality, and engagement. Mentzer et al. [24] under collaboration in SC defines 'a business process in which collaborating partners work together to achieve common goals that are mutually beneficial to partner companies'.

One of the preconditions for the successful functioning of SCs is quality business relations and collaboration between members of the SC [25-27]. The impact of the relationship between the members of the chain on the performance of the SC has often been investigated [26,28-31], and the research of these authors confirmed that the performance of the SC is significantly improved if there is a high level of trust and attachment among the partners in the SC.

One factor that often proved as having an important influence on SC performance is SC RQ [28,32-34]. RQ represents a degree to which SC members are involved in an active, long-term relationship [35], which, based on their past experiences of success or failure, answers to their mutual needs and expectations [36]. In the literature, RQ is conceptualised as a latent variable of different components mostly derived from social psychology, such as trust, commitment, and satisfaction [37-41].

Due to the specificity of AFSCs and the significant differences in relation to non-AFSCs, 'collaboration' and 'trust' are crucial for a better flow of products and information, as well as for competitiveness and performance of the individual chain members and for the entire chains-thus providing improved contact methods and joint solutions for the growing issues related to food quality and safety, and other difficult-to-detect attributes of food products [42].

\subsection{Collaboration}

Based on the analysis of previous research, we can conclude that the important categories of RQ in AFSCs are: appropriate inter-organisational collaboration [20,27,43-46], effective communication $[44,44,47,48]$, mutual exchange of information $[43,47,49,50]$, resource sharing (physical, financial, human, and organisational) [45,47,49,50], willingness to share risks [51], transparency between partners [52,53], relationship quality and commitment [44,46,54], and the presence of trust between partners in the SC [43,46,55-58]. Accordingly, the most important variables of RQ in the AFSC, used in our research, will be further explained.

\subsubsection{Inter-Organisational Collaboration}

Since collaboration is based on relationships, either at the interpersonal or organisational level in the context of SCM, there is also intra-organisational or internal collaboration, which refers to collaboration within organisations, and interorganisational collaboration, which refers to the collaboration of all members in the SC [59]. Internal collaboration refers to the organisation's culture of collaboration (for example, the existence of elements of trust and commitment). External downstream collaboration includes customer relationship management, while external upstream collaboration includes supplier management. There can be different levels of relationships within a SC, and collaboration in the context of inter-organisational relations is very important, because when it comes to developing the RQ between companies or SC stakeholders, it is crucial to achieve prerequisites for successful collaboration.

\subsubsection{Quality of Communication}

Another important category of collaboration and one of the prerequisites for trust is communication between business partners. Effective and efficient communication is a prerequisite for quality collaboration [47]. Through continuous and honest communication, SC problems can be avoided, and solutions can be more easily found, which greatly simplifies and improves collaboration among SC members [48]. 


\subsubsection{Information, Risk, Knowledge, and Resource Sharing}

Information sharing is a key feature in the collaborative category, as information sharing not only reduces uncertainty among business partners, but leads to better efficiency, flexibility, and faster response of the entire SC [22]. Except for the poor availability and high prices of the products, the imbalance between supply and demand, and high operating costs, the lack of information flow between the chain actors in organic food SCs is one of main hindrances to the growth of the organic market [49].

A good collaborative relationship requires not only trust and commitment, but also a willingness to share exposure to risk to achieve the mutually agreed long-term goals [25]. Sinha et al. [60] also state that one of the main contributors towards SC risk is a lack of trust. Therefore, incentives need to be put forward clearly and knowledge about risks needs to be assessed and managed properly.

Resource sharing is also one of the subcategories of collaboration and differs from information sharing in its physical nature. While the latter refers to the sharing of data and information, the sharing of resources between partners in the SC implies the sharing of physical, financial, human, and organisational resources [61]. However, companies not only share information and resources with each other, but if they work together, they share knowledge [49] and risks. As a result, uncertainty among SC members is alleviated.

Transparency between SC partners improves communication within the SC and increases information exchange, which can lead to successful collaboration and can improve overall supply [52]. Transparency is particularly important in the case of pricing [53], which can significantly affect trust between partners and the loyalty of suppliers.

\subsubsection{Relationship Quality and Commitment}

Quality collaboration between different stakeholders in the food value chain is extremely important and depends on many factors. Wilding and Humphries [62] list ten attributes that encourage SC collaboration: reliability, long-term focus, communication, stability, win-win, trust, willingness to compensate, personal relationship, creativity, and C3 (cooperation, collaboration, and coordination). Bezuidenhout et al. [51] believe that a lack of attributes, such as reliability, trust, good personal relationships, and communication, causes fragmentation, opportunism, and a desire for excessive control of individuals in the chain. Aji [57], in her research, points out four key variables for relationship building: satisfaction, trust, and two dimensions of commitment-commitment to continuity and commitment to support. Schulze et al. [44], in a study of RQ in the German pork sector, also argue that $R Q$ must be conceived as a construct that encompasses satisfaction, trust, and commitment.

Collaboration is vital for the empowerment of small farmers, especially those in communities with low socio-economic status. As key stakeholders in the AFSC, farmers typically have limitations in business skills, aspirations, and systemic thinking; thus, they often focus heavily on their business rather than creating an integrated collaborative system. Conflicts and misunderstandings can be minimized by understanding and managing the factors, i.e., the preconditions of quality collaboration, in partnership in the AFSC.

Commitment reflects the organisation's faith and dedication to maintaining and improving relationships with partners to work together to create value in the long run. Similar to trust, it is one of the most critical behavioural factors for successful collaboration in an AFSC [15]. Trust and commitment lead to the creation of loyalty in relation to a business partner.

\subsubsection{Long-Term Orientation}

Long-term, sustainable partnerships require a long-term orientation and high level of collaboration between all parties in the SC, and are characterized by high levels of trust, commitment, transparency, and integrity. As satisfaction increases, there are always expectations of relational continuity and the tendency of both parties to stay in longer-term relationships $[38,63]$. Satisfaction with past outcomes indicates that there is equity in the 
relational exchange. Equitable outcomes provide confidence that either party is not being taken advantage of in their relationship and that both parties have concern about the other's welfare [38]. Where there are high levels of confidence, trust is established. Furthermore, when trust is established, both parties are more committed to their relationships $[29,64-67]$.

\subsubsection{Power, Dependency, and Opportunism}

In addition to the previously mentioned and described factors that enhance collaboration among partners in the SC, there are also those that can negatively affect the development of collaboration and ultimately the success of AFSCs, such as excessive use of power, dependency, and opportunism.

Power and dependency are regarded as a fundamental issue in the SC. The power factor defines the ability of a person or organisation to influence the behaviour, decisions, and actions of others. Power grows from organisations that have valuable resources or control over resource allocation [68]. The more powerful an organisation is, the more it will be able to influence the types of information shared, the recipients, and the sharing mechanism in collaborative activities. However, the power function should not be used to exploit weaknesses, but as support and assistance in finding solutions and better ways to solve partnership problems, increasing mutual benefits, and competitive strategies [15].

Opportunism is a risky situation in which companies and individuals seek to take advantage of a situation. In inter-organisational relations, opportunism occurs when one or more parties exploit the vulnerabilities of other parties in search of their own unilateral gain at the substantial expense of the other parties and/or the entire relationship [69]. Hobbs [70] states that the risk of opportunism increases in certain situations in SCs, where the bargaining power of the chains is not evenly distributed. For example, when there are only a few buyers of products from many suppliers, as for most agricultural products in rural areas. Farming companies in the fresh produce SC usually have little bargaining power [71]. Therefore, there is a high risk that customers will act opportunistically. Some examples of opportunistic customer behaviour (e.g., retailer) are as follows: the retailer controls all information and does not share it with producers, does not treat the supplier fairly and honestly (i.e., as an equal partner in the SC), does not care about the welfare of the supplier or their interests and well-being, etc. The lower the opportunism of the SC partners, the greater the trust in the entire SC network, i.e., the greater the trust in the SC.

\subsection{Trust}

Trust is a central component of AFSCM and only in this way can the FSC be successful. Trust is an important strategic condition and one of the main factors that can improve or limit (in case of distrust) successful collaboration in the agri-food chain. In the agricultural sector, trust is more important for small and medium-sized enterprises (SMEs), which characterize the existence of personal relationships between business partners [72,73].

There is no single definition of trust and different authors distinguish different forms of trust in business relationships. Trust is considered to exist if 'one side believes the other is fair or well-intentioned' [74]. 'Trust can be viewed as the opposite of opportunism in business relationships. We therefore define trust as the belief that a business partner can rely on fulfilling its obligations in a situation involving risks and vulnerabilities' [75].

In operational terms, 'trust' refers to the belief that the other party is sincere and honest and under no circumstances will intentionally do anything that would damage the relationship. Quality collaboration, trust, and commitment are important prerequisites for food quality as some of the important indicators of the success of the AFSC [76].

For trust among business partners to develop successfully, certain preconditions of trust must be met. Different literature has identified different preconditions of trust within the AFSC. Batt [43] identifies perceived honesty, credibility of information, reliability of promises, relationship satisfaction, compatibility of goals, and relationship investment as factors that create trust in the fresh product chain. Puspitawati et al. [52] list eight precursors of trust in AFSC: communication, price transparency, price satisfaction, price 
quality ratio, joint problem solving, partner reputation, dependence, and relationship flexibility. Numerous authors agree that the most important determinants of trust in the AFSC are the quality of communication achieved by communication frequency and information quality, along with a positive collaborative experience $[44,49,77]$.

The higher the level of trust between the partners, the more likely it is for longterm collaboration to develop. After a high level of trust, quality collaboration, good communication, and strong personal relationships develop between the partners, the parties begin to engage in activities such as joint product development, co-investment, or innovation capacity development [30].

\subsection{Overall Performance}

Collaboration and trust can help improve the efficiency of the AFSC. SC performance refers to the overall performance of a chain, and depends on the performance achieved at each stage of the SC [78]. Therefore, it is important to improve not only the performance of individual members in the SC, but of all members in the SC. The findings of one study [71] showed the positive effects of collaborative relationships on SC performance, including financial, innovational, operational, environmental, social, and economic performances. In practice, there are many performance indicators that mainly depend on the specific characteristics of the SC, which is why there is no single definition of performance indicators. Measuring process performance is extremely important in an AFSC. Competitive advantage is among the main strategic goals of the AFSC and can be generated and consolidated not only through the exchange of resources and information, but also through other indicators, such as cost, delivery and delivery speed, quality, and flexibility [47]. In this paper, performance is observed through the following variables: improvement of business processes (coordination and optimization), operational efficiency (e.g., optimal use of resources in the SC), optimization of inventories, reliability and speed of delivery, demand planning, reduction of total costs for both parties (e.g., logistics), flexibility in delivery quantity, delivery time, fast resolution of complaints (implying responding to them), customer and end consumer satisfaction, making higher profits, achieving better competitive advantage in the market, offering low prices and prices even lower than competitors, declining opportunistic behaviour (more mutual respect, work for the benefit of both parties), increased product quality, increased communication between buyer and seller, achieving mutual benefits in business, reducing risk for both parties, reducing/optimizing inventory, and introducing and/or improving online retail.

\section{Case Study: Organic Food Market in Croatia}

\subsection{Level of Development of the Organic Food Market}

Like the rest of the world and Europe, Croatia is raising awareness and concern for human health and the preservation of the planet Earth. With the raising of awareness, the area under organic agricultural production also increases. According to the Croatian Ministry of Agriculture [79], the area under organic production in Croatia is constantly increasing. Table 1 shows the areas of used agricultural land, the areas under organic production, and the share (in percent) of areas under organic production in the total used agricultural areas of Croatia for the period from 2013 to 2020, and strong growth in organic production is evident.

Of the 15.6 hectares of organic agricultural land in Europe, 8 million hectares, or 7.7\%, accounts for EU agricultural land [2]. Table 1 shows that in 2019, the share of areas under organic production in the total agricultural land in Croatia was $7.18 \%$, which is almost identical to the EU average. However, Croatia is still in a distant 26th place when measured by area of organic agricultural land. Half of Europe's organic agricultural land is located in four countries. The country with the largest area of organic agricultural land is Spain ( 2.2 million ha, which is more than $14 \%$ of the total European organic agricultural land), followed by France, Italy, and Germany [2]. 
Table 1. Areas of used agricultural land and areas under organic production in Croatia for the period from 2013 to 2020.

\begin{tabular}{cccc}
\hline Year & Used Agricultural Land (ha) & Areas under Organic Production (ha) & $\begin{array}{c}\text { Share of Area Under Organic Production } \\
\text { in Total Utilised Agricultural Area (\%) }\end{array}$ \\
\hline 2013 & $1,568,881$ & 40,660 & 2.59 \\
2014 & $1,508,885$ & 50,054 & 3.32 \\
2015 & $1,537,629$ & 75,883 & 4.94 \\
2016 & $1,546,019$ & 93,814 & 6.07 \\
2017 & $1,496,663$ & 96,618 & 6.46 \\
2018 & $1,485,645$ & 103,166 & 7.94 \\
2019 & $1,504,445$ & 108,169 & 7.18 \\
2020 & $1,506,205$ & 108,659 & 7.21 \\
\hline
\end{tabular}

Source: Ministry of Agriculture [79].

The basis for a stronger development of organic agriculture in Croatia is the adoption of the Law on Organic Production of Agricultural and Food Products in 2001. Until the enactment of this Act in Croatia, organic agriculture was practiced by ecological associations and enthusiasts [80]. Organic food producers have recognized the potential of the market and their number is growing exponentially. Due to climatic and relief differences, clean soil and natural benefits, Croatia has the potential for the development of organic agriculture; however, its more serious further development is slowed down by numerous barriers. The fragmentation of agricultural areas, the low share of areas under organic production, unsettled property and legal relations, unsustainable production, insufficient connection or collaboration (often ignorance) of domestic producers of organic food products, inability to reach market infrastructure, and lack of strategy and long-term planning for organic agriculture (i.e., the state's commitment to organic agriculture) are unfavourable factors in the development of organic agriculture.

In Croatia, most farms engaged in organic production are small family farms (OPG), which also face several challenges. Although Croatian organic farms are small, mostly about five hectares and even smaller [81,82], and cannot meet some world market standards, Croatia is a country that has recorded a significant increase in areas under organic production in the last 10 years.

According to the data from the Register of Entities in Organic Agriculture published by the Ministry of Agriculture [79], the number of entities bearing the organic food certificate in Croatia in 2019 was 5548, and the latest data indicate a further increase to 5937. Although the number of organic producers in Croatia has been growing significantly in the last 5 years, as far as processors are concerned, Croatia lags far behind other European countries. Table 2 shows the trends in the number of organic producers and processors in Croatia for the period from 2013 to 2020.

Table 2. Number of organic agricultural entities in Croatia from 2013 to 2020.

\begin{tabular}{ccccccccc}
\hline & $\mathbf{2 0 1 3}$ & $\mathbf{2 0 1 4}$ & $\mathbf{2 0 1 5}$ & $\mathbf{2 0 1 6}$ & $\mathbf{2 0 1 7}$ & $\mathbf{2 0 1 8}$ & $\mathbf{2 0 1 9}$ & $\mathbf{2 0 2 0}$ \\
\hline Agricultural producers & 1608 & 2043 & 3061 & 3546 & 4023 & 4374 & 5153 & 5548 \\
Processors & 181 & 237 & 320 & 312 & 357 & 368 & 395 & 389 \\
Total & 1789 & 2280 & 3381 & 3858 & 4380 & 4742 & 5548 & 5937 \\
\hline
\end{tabular}

Source: Ministry of Agriculture [79].

\subsection{Distribution Channels of the Organic Food Market}

Distribution channels for organic food products in Croatia are mainly related to the terms 'local market', 'alternative market', 'direct sales', and 'short supply chains' because most organic products in Croatia are still sold through direct channels, and a smaller percentage of domestic producers distribute their products through retail [80]. The results of the Hamzaoui-Essoussi and Zahaf [83] study showed that small communities tend to support local organic food producers for three reasons: (1) low availability of organic food in supermarkets in small communities, (2) higher consumer confidence in local farmers 
than in retailers, and (3) direct marketing and distribution of food products from the local supplier to the consumer. Combining sales in short chains with organic farming practices is associated with higher farmer income, and economic performance depends not only on factors at farmer and farm-level (especially skills and labour organisation), but also at chain and territorial levels (e.g., degree of local competition and profit margin allotted to the intermediary) [84]. Retailers need to be aware of the different needs of consumers in small communities compared to large cities. For example, price does not significantly affect the customer's purchase decision, but customers' trust in the manufacturer is more important.

The main distribution channels for organic products on the European market are indirect, i.e., supermarket chains followed by specialized stores.

Digital technologies, such as big data and the Internet of Things (IoT), are widely considered as promising new tools for both increasing productivity and competitiveness in the agri-food sector and ensuring a more sustainable use of resources. Knowledge and insights derived from ever-increasing volumes and a variety of digital data may help to optimize farm production processes, improve risk management, predict market trends, and enhance strategic decision-making capabilities [85]. The digitization of the agri-food sector is a strategic priority in the political agenda of European institutions, and new technologies together with digitalisation are transforming agriculture and offering new opportunities to improve policy. The opportunity to improve the competitiveness and efficiency of the sector offered by new technologies comes together with its potential to face new economic and environmental challenges [86].

With the development of technology and the internet, more and more businesses are doing business through online channels, which makes their products easily available to consumers almost around the world. Consumers on the other hand, with the faster lifestyle and need to save as much time as possible, have embraced this new online channel for shopping to meet their needs. The online channel has experienced exponential growth especially during the COVID-19 pandemic due to the prohibition or limitation of the business of traditional retail channels, fear of citizens of a pandemic, and many people with self-isolation measures and quarantines for which it was the only way to buy products. Due to the occurrence of the COVID-19 pandemic, the e-commerce industry has experienced rapid development [87], and agricultural producers have also adjusted to intensively use this distribution channel for the sales of their products. Very often, e-commerce is especially used in organic food purchase, especially in western European countries. The various alternatives that allow consumers to purchase organic products online now include the websites of major food retailing chains, which compete with smaller companies that operate exclusively on the internet. The internet has also become a powerful relational marketing tool that acts as an instrument of social interaction, making it possible not only to attract consumers but also to secure consumer loyalty. Consequently, a mechanism to boost the home market consumption of organic products can be found in technology [88].

Only a few Croatian organic food producers can compete in retail chains with foreign organic producers. The reason for this is the low ability of farmers to operate independently in the market. In addition, distribution within the organic food sector is quite inefficient. Although there is interest in expanding the organic food market, there is a lack of studies that address the distribution channels of organic food in developing countries, such as Croatia [5].

Prior research has shown that usage of distribution channels for organic food products depends on different stages of development of the organic market in individual countries (e.g., emerging markets or mature markets), and organic producers also market their products through different channels $[6,67,89]$. Additionally, due to the specifics of organic production and the small production quantities, depending on the number of stakeholders involved and the type of product (fresh or processed), distribution channels may look different. Figure 1 shows an overview of the usual distribution channels for organic food products in Croatia. Organic food producers in Croatia mostly use direct distribution 
channels (on-farm sales, specialized fairs, and home delivery) because they produce small quantities and mostly produce fresh organic products [5]. In terms of indirect distribution, specialised stores are the dominant form of retail, especially when it comes to organic products, followed by wholesale. Domestic supply generally cannot meet demand and domestic retail chains selling organic products offer a variety of imported products. A small number of organic producers sell their products through small grocery stores and emerging distribution channels, such as hotels, restaurants, and cafes (Ho-Re-Ca).

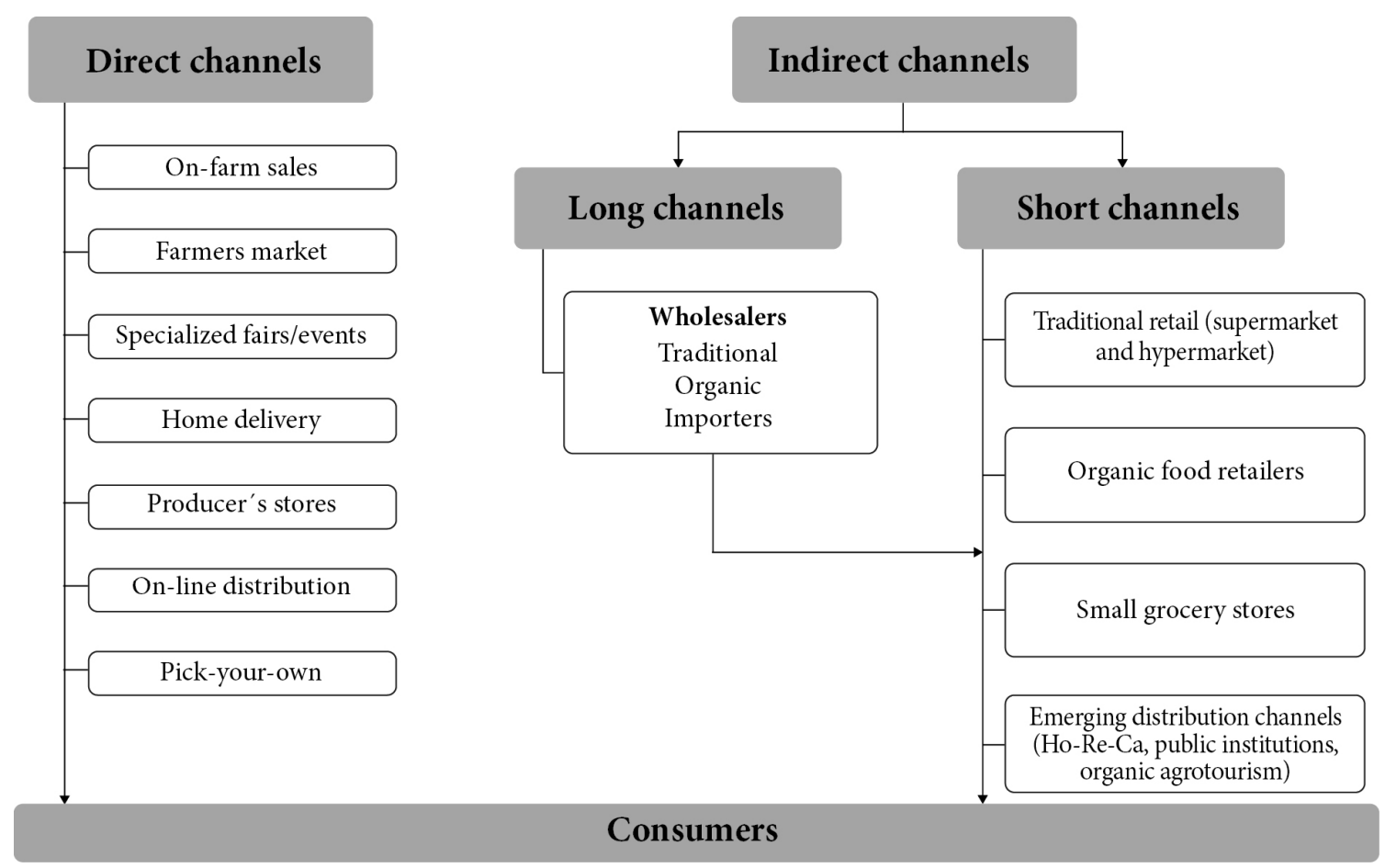

Figure 1. Distribution channels in Croatian organic food market. Source: own interpretation.

\section{Empirical Research}

\subsection{Methodology}

Figure 2 shows a detailed elaboration of our research design (i.e., steps of research design, objective, techniques used, and outcome). In this study, we used in-depth interviews that provided better access to the thoughts, attitudes, and motivational ideas of organic food producers (according to [90]). Respondents were informed that the data provided during the in-depth interview would be used exclusively for scientific purposes, and that the individual data on organic food producers would not be used, but only aggregate data, which would guarantee the anonymity of the research.

First, a sample of respondents with the desired characteristics was found. Criteria for selecting the organic food producers in the sample were the following: minimum three (3) years of active business operation in the market (i.e., selling to retailers), equal distribution of the number of respondents regarding the type of product (fruit, vegetables, meat and meat products, milk and dairy products, and finished products, e.g., honey) and the size of the family farm (production quantities). This study was an exploratory field study in the Croatian organic food market. Using a semi-structured interview questionnaire (Appendix A), data collection was performed through in-depth interviews with six organic food producers in Croatia from March to August 2021. 
Step 1: Systematic literature review

Systematic literature review provides readers with a state-of-the art understanding of the research topic, help identify research gaps and signal future research avenues.

Objective: For this research, a systematic literature review was conducted with the aim of identifying and analysing research papers on the topic of relationship quality (collahoration, trust, and performance) in the AFSCM

Techniques: Systematic literature review was conducted using the Web of Science Clarivate Analytics database.

Outcome: Identified research papers on the topic of relationship quality (collaboration, trust, and performance)

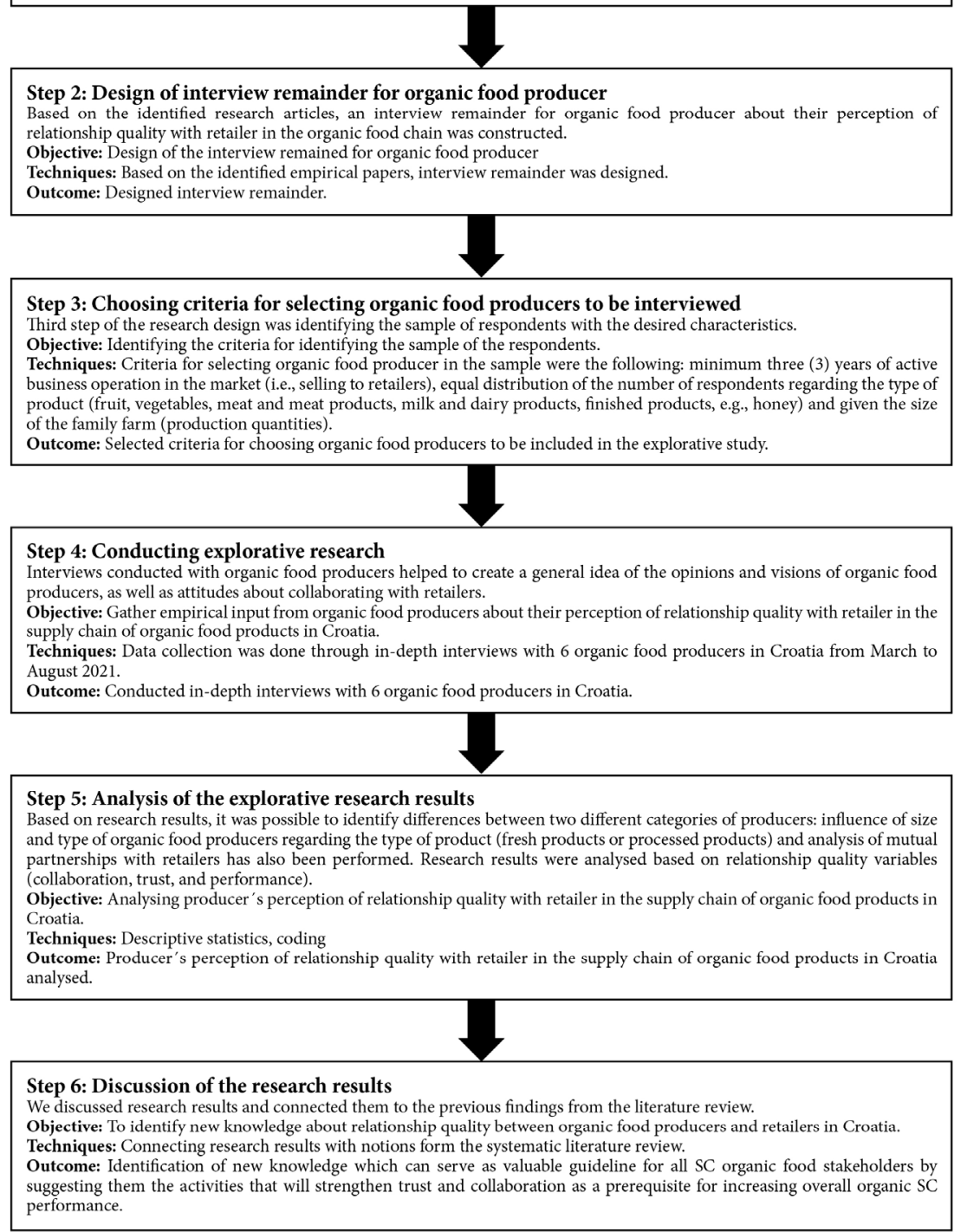

Figure 2. Research design.

Interviews conducted with organic food producers helped to create a general idea of the perceptions and visions of organic food producers, as well as attitudes about collaborating with retailers. It was also possible to identify differences between two different categories of producers and the influence of the size and type of organic food producers regarding the type of product (fresh products or processed products). An analysis of mutual partnerships with retailers was also performed.

The interview questions covered several topics $[90,91]$ and the interview reminder consisted of 4 parts. In the first part, the respondents were asked about the structural characteristics of their production unit and their motives for engaging in organic production. The second part consisted of questions about the market and distribution of products (where they sell products and through which distribution channels). The third part focused on the relationship between producers and retailers of organic food products, with an emphasis on collaboration, trust, and performance. The last part was of an open type and referred to proposals for market development. Within the third part, organic food producers were asked about: inter-organisational collaboration, quality of communication 
with buyers (retailer), information, risk and resource sharing, relationship quality and commitment, long-term orientation (common plans and interests), power, dependency, opportunism, trust in the buyer, and overall SC performance.

The questions were deliberately expanded to allow respondents as much freedom as possible in their answers. However, in this paper, we focus on the third and fourth part of the interview reminder, which contains topics important for this discussion and textual evidence from the interview. The research findings were taken from the respondents themselves, which provides much more information and helps the goal of the research. All interviews were first recorded to increase data accuracy [92] and later transcribed to allow detailed analysis [90,93].

Intra-case analysis involved writing a summary of each individual case to identify important facts, with a special focus on the main category of perceiving differently the main indicators of collaboration quality and relations with retailers. Following this process, a coding scheme was developed to assist in cross-case analysis [92,94] that included identifying similarities and differences in the attitudes of Category 1 and Category 2 respondents [90], which is shown in Appendix B. The respondents were divided into two categories according to the intensity of their collaboration with the retailers. Category 1 consisted of two organic food producers who sell more than $50 \%$ of their products through retailers, while Category 2 consisted of four organic food producers whose dominant sales channel is direct selling at fairs and home delivery (approximately $80 \%$ ) while the remaining $20 \%$ of sales is accomplished through the retail channel. Both Category 1 and Category 2 producers perceived differently the main indicators of quality collaboration and their relations with the retailers due to the size of the producer (i.e., its production capacities), different product characteristics (fresh products or processed products), and collaboration with the different retailers regarding their size and specialization. The gender structure of the sample was $50.0 \%$ men and $50.0 \%$ women. The age structure of the sample slightly shifts to older respondents. Furthermore, half of the respondents had completed secondary school and other half of the respondents completed high school or had a university degree. Five producers were registered as family farms, while one producer was registered as craft. Most producers $(66.7 \%)$ stated that employees were family members and themselves. The key motives for organic production were primarily personal beliefs of producers $(n=3)$, followed by self-employment $(n=2)$, and health reasons $(n=1)$.

\subsection{Results}

The analysis of the results follows, with the inclusion of presentations of the key primary research evidence that was used in drawing conclusions. The main text discusses the research findings and provides some textual evidence supporting the statements from the interview reminder, and Table A1 contains additional abbreviated textual evidence for each of the two categories of respondents on the similarities and differences in their responses. A review of the literature, as well as the coding scheme, also facilitated in reporting the research findings.

\subsubsection{Research Results of Inter-Organisational Collaboration}

Category 1 producers mostly achieved formal/contractual collaboration with the specialized organic food retailers and with large retailers, such as retail chains, and to a lesser extent with small retailers. Contracts with the specialized retailers defined the quantities in advance, while contracts with large retailers were undefined in terms of quantities and deliveries were based on weekly supply and demand, rendering such sales unsafe for the producers. In addition, retailers required strict and controlled product quality. On the other hand, collaboration with small retailers was often informal and based on agreement and mutual trust, which is also typical of the smaller Category 2 producers. They mostly did business with small retailers because they could not provide the required quantities for the large ones. In spite of the flexibility, it was difficult for them to plan quantities because orders lacked continuity. Both categories of producers 
deemed that each side was oriented towards achieving its own goals, that there was no joint business planning, and that retailers mostly sought earnings. In both cases, positive past collaboration significantly affected the acquisition of trust in the relationship.

\subsubsection{Research Results of Quality of Communication}

Category 1 producers considered that they had quality, open, and frequent communication, especially with the specialized retailers that had departments in charge of informing their suppliers (e.g., about changes in legislation, standardization, etc.). Although they mostly communicate indirectly (online, etc.), they pointed out that it was very important for them to communicate 'face to face' with the retailers as often as possible. Category 2 producers mainly communicated informally with their buyers and also considered communication to be of high quality and very open. Both categories of organic food producers stated that communication with the retailers had a positive impact on the performance of their collaboration. Both groups of organic food producers affirmed that the first contacts with the retail distribution channel were mainly established at specialized eco-fairs, and that the frequency of communication depended significantly on the type of the product (fresh or processed).

\subsubsection{Research Results of Information, Risk, Knowledge, and Resource Sharing}

Category 1 producers generally exchanged information with the retailers about the quantities and quality of their products. With the specialized retailers, this information was timely, specific, and more accurate than with the other retailers, and it was consequently described as high quality, open, and honest. They even had an understanding regarding possible changes in the quantities of production in case of unforeseen circumstances. Specialized retailers also informed their suppliers about changes in legislation, in demand, etc. Sometimes they intervened with financial aid, for example in the form of an advanced payment so that the producer could prepare the product, and occasionally they engaged in joint promotions.

Category 2 producers pointed out that they had a more personalized relationship with small retailers and that there was a better interaction with the small retailers in terms of information about the demand for their products. In this way, long-lasting trust was created. However, retailers did not provide them with financial assistance and joint promotions. Unfortunately, both groups of producers were consistent in the conclusion that retailers were not interested in participating in the development of new products and found it difficult to accept them, and that there was no sharing of resources, such as warehousing, transport, etc., nor of production risks. In addition, retailers did not inform the organic food producers about the creation of and changes in retail prices, and there was no sharing of information about business performance.

Collaborative integration between actors in organic SCs is an opportunity to exchange information, expand knowledge, and solve problems together. Farmers must deepen their knowledge and skills regarding production technology, market conditions (e.g., new forms of sales and distribution channels, promotional activities), and formal and legal procedures as well as strengthen their competitive advantage over other market participants [95]. Networking with the various actors in the organic food sector is recommended, especially with retailers.

\subsubsection{Research Results of Relationship Quality and Commitment}

Category 1 producers believed that specialized retailers were reliable and secure customers and were mostly satisfied with the quality of the relationship. Although they did not participate in production planning, specialized retailers showed understanding for the producers' problems regarding agricultural production. If problems arose, the retailer was ready to help and resolve them promptly. The producers expressed loyalty and commitment to the retailers, as working with them enabled them to develop professionally. 
Even if they had offers from alternative buyers, they would continue selling to their retailer (buyer).

Category 2 producers emphasised that their collaboration with the retailers, who were mostly trustworthy, was improving steadily. They were mainly committed to a quality relationship and collaboration with their retailers. Both categories of organic food producers solved problems and disagreements with the buyers quickly and often informally. Disagreements between retailers and producers were mostly rare, but both groups reported much less intensive collaborations with the large retailers.

\subsubsection{Research Results of Long-Term Orientation}

Category 1 producers stressed continuous efforts on improving long-term collaborations with their retailers and agreed that both parties invested significant efforts in developing quality long-term relationships and often discussed their mutual expectations. They also worked together on planning future demand. However, Category 2 organic food producers did not work continuously on improving long-term collaboration and generally did not discuss mutual expectations with their retailers. Both categories of producers did not collaborate with their retailers on joint production planning and the development of new products. All expected to continue and further develop their existing collaborations, but they were also open to collaborating with other, alternative retailers.

\subsubsection{Research Results of Power, Dependence, and Opportunism}

Both categories of organic food producers believed that, with the large retailers, the amount of production could affect their bargaining power. However, they also pointed out that as production increased, they became increasingly dependent on the retail chains. They also agreed that retailers had more bargaining power in the SC, although still not full power. All organic food producers stated that there were alternative buyers on the food market for them. The first category believed that product quality also had a significant impact on their bargaining power (especially with regard to processed products). Additionally, they felt that smaller customers did not dominate as much, that they were more flexible, and that they sometimes took products that they had not ordered. However, they ultimately said that 'it turns out that retailers impose conditions' because the producers must comply with what the retailer requires (quantity, method and time of delivery, etc.) i.e., through contracts. Both categories of organic food producers agreed that the retailers did not always follow only their own interests but respected the traditions and beliefs of the organic food producer.

\subsubsection{Research Results of Trust}

Category 1 organic food producers had great trust in the retailers, due to the high integrity in the SC and to their long-term collaboration as the basis of the trust. They believed in the sincerity of the retailers' advice and expertise, as well as in the information and data they provided. They believed that the retailers generally kept their promises and treated them fairly and justly; hence, in the case of uncertain circumstances, they would remain loyal to the retailers. Furthermore, in terms of trust, they would recommend collaborating with their retailer to other suppliers. Nevertheless, the second group of organic food producers did not have complete confidence in their retailers. They believed in the expertise and the advice that the retailers shared with them, but they did not fully trust the information. Trust was also based on long-term collaboration and good reputation in the market, i.e., with the consumers. Customers were generally honest and kept their promises, but relationship problems could undermine customer loyalty. Since they felt that their retailers generally treated them fairly and justly, they would recommend their buyers to other suppliers. 


\subsubsection{Research Results of Overall Performance}

Regarding the impact of collaboration and trust on business performance, Category 1 producers believed that collaboration and trust had a significant effect on improving communication, reducing business risk, and optimizing the use of resources and inventories in the $\mathrm{SC}$ as well as demand planning, the speed of resolving complaints, forming prices lower than the competition's, introducing and/or improving online business, and reducing opportunistic behaviour of retailers. They also believed that the quality of collaboration and trust in the retailer influenced them to increase profits, improve product quality, and achieve a better competitive advantage. Collaboration and trust did not significantly affect their operational performance, such as reliability and speed of delivery and lead time.

In Category 2, completely opposite perceptions of organic food producers were identified, as collaboration and trust significantly affected the reliability and speed of delivery and lead time. However, they did not significantly influence the optimization of the use of resources, SC optimization, demand planning and complaint resolution, lower-thancompetition pricing, increasing profits, introduction and/or improvement of e-business, the quality of communication, the reduction of business risks, or the reduction of opportunistic behaviour by the retailers. In short, collaboration and trust did not affect the improvement of product quality in the slightest.

In addition, the findings of the study showed the positive effects of collaborative relationships on supply chain performance, including financial, innovation, operational, environmental, social, and economic performances [71].

\subsubsection{Suggestions for Market Development}

All producers also perceived the problems in the market of organic agri-food products and gave the following recommendations for the development of that market. As one of the bigger problems, they pointed out the poor information about organic products for consumers, who often do not notice the difference between domestic, peasant, and organic production. They believe that more effort should be put into promotion, in which the competent institutions should be involved. The representation of domestic products in stores needs to be strengthened, and retailers should reduce margins so that organic products are more affordable for consumers. They believe that the control of organic producers should be strengthened, due to the unfair competition of producers who present themselves as such. The association of organic food producers, the construction of joint distribution centres with the necessary infrastructure, and the organisation of special stands for organic producers in the markets were some of the other proposals. They also believe that producers should be more oriented towards processing, as this would allow them to be present on store shelves and to achieve greater added value for their products.

\section{Discussion}

The results show that inter-organisational collaboration with retailers is of greater importance for Category 1 producers because they sell about $50 \%$ of their products through retail channels. Organic food producers recognize the importance of working with the retailers to make sales easier. Contracts with the specialized retailers that define conditions enable better production planning and better development of trust in the retailer. A study [93] found that some producers use contracts for making an investment or promoting a product, which is important to ensure their brand image among the customers. Additionally, Australian vegetable growers prefer contractual relationships to ensure stable prices. This finding is in line with another study [44] where the authors found that contracts are a highly preferable option for vegetable producers in bringing down the price risks.

The sale of products to large retailers is not safe for organic food producers because the contracts are not pre-quantified, which affects the uncertainty of production for the organic producers and can cause surpluses or shortages. In general, there is no lasting and secure collaboration and there is a great deal of uncertainty. According to [96], the higher the uncertainty in the chain, the lesser the trust will be. As collaborative advantages among the 
chain partners and their willingness to collaborate increases, trust builds up. Uncertainty occurs with smaller organic food producers (Category 2 ) who mainly collaborate with smaller retailers, because this collaboration is not safe nor concretely and clearly defined. The agreements are based on the ordered quantities, on which the rebates or sales prices also depend. Smaller stores mostly work with smaller organic food producers, and they find it difficult to commit to buying certain quantities of products regularly. On the other hand, it is the flexibility in order quantities here that is a favourable feature. Collaboration with small retailers in both cases is mainly based on trust and verbal agreements. In this way, organic food producers and retailers communicate more often, relationships are more flexible, and it is easier to adapt to market changes, which is in line with the findings of [97].

Category 2 organic food producers still prefer to sell products directly because they have little bargaining power compared to large retailers. In addition, since their production is small, it is more profitable and safer for them to sell directly to final consumers, where there is no delay in payment. This research showed that the producers are not dependent on retailers because they sell small quantities (about $20 \%$ of total production), which does not affect their profits significantly. This is contrary to the research of Sun et al. [58]. According to their findings [58], due to the significantly higher number of suppliers compared to buyers of organic products, suppliers must rely on retailers or distributors in many ways to secure their profits. Given that countries differ significantly in the level of organic food consumption and production, especially in relation to the share of conventional production, Orsini et al. [6] conducted a study in eight EU countries and divided organic food markets into mature and new markets. The organic market is developed in Germany, France, Great Britain, Italy, and Spain, while Hungary, the Czech Republic, and Estonia have new organic markets. The Croatian organic food market is also one of the new markets in terms of its characteristics. Findings of FiBL [20] and the research by Orsini et al. [6] show that most organic food in Europe's mature markets is sold through supermarkets, while a smaller number of organic food farmers sell their products directly to consumers or through 'alternative' chains, such as specialized organic food shops, box schemes, markets, etc. These data were not specified for specific products and depending on the type of product the distribution channel can differ significantly. The results from Orsini et al. [6] do not confirm a clear distinction between mature and emerging markets, as shown in previous studies $[98,99]$. However, our study confirmed that the Croatian market belongs to the new market category, and is still underdeveloped in terms of demand, where organic food is still mostly sold through direct distribution channels, although this can sometimes be influenced by the type of product (fresh or processed) and not only the phase of development of the organic food market [6]. The problem with distribution through retailers, in relation to direct sales, is both strict standardization and quality requirements, especially for fresh products (size, colour, etc.), which is difficult to achieve in agricultural production, especially organic. Product quality is an important aspect of contractual collaboration in the Indonesian supermarket channels [97]. Our study showed that, due to the standardization requirements and often undefined contracts, organic food producers often have surpluses that they try to place on the market through direct sales channels.

The results also show that organic food producers are generally satisfied with their communication with the retailers. Orders or quantities depend on the type of product and the season, which significantly affects the frequency of communication; communication is more frequent in the season, but often sporadic as there is no continuity in orders. In selling fresh products, the communication is dynamic ('you have to be always ready'), and 'just in time' delivery is expected; hence, communication by phone or by e-mail takes place on a daily basis. Processed products require less active communication due to their longer shelf life. Producers communicate with the retailers mainly about orders, deliveries, and collecting goods. Moreover, the findings of [48] indicate that the communication between the retailers and the suppliers of organic food products is somewhat limited to short-term activities concerning the role and terms of the products in their focal assortment. The same authors believe that the farmers' mistrust towards the retailers suggests that some form 
of communication is necessary for the creation of trust; however, they point out that the frequency and the form of communication are less important than its quality. In our study some of the smaller producers believed that they were 'still learning to communicate' with retailers. Informal collaboration also results in informal communication that is high quality and open but does not significantly affect its success. The research results from Fischer [100] indicate that trust in SC partners can be improved significantly by effective communication and by positive past collaboration. We believe that quality communication can only be achieved if relevant information, knowledge, resources, and risks are shared, especially from the point of view of small farmers who are at a disadvantage compared to the retailers. According to Sun et al. [58], retailers are usually in a dominant position in AFSCs, and when they attach importance to sharing information the suppliers will perceive it as fair.

The results of this study indicate problems in the exchange of information between organic farmers and retailers. The exchange of information depends a great deal on the type of retailers with which the organic food producers collaborate. Retailers do not exchange information about production processes because retailers are less informed and have less knowledge about it than producers; thus, there is a sharing of knowledge about market factors but not about organic production. Poor knowledge sharing is not unique to organic chains but is found in other food chains as well [49]. Findings of Anastasiadis et al. [101] point to the problematic flow of information within the SC resulting in minimal trust among stakeholders. However, our study showed that although organic food producers are not completely satisfied with the exchange of information, given the type and quantity, they still believe that the information received from retailers is mostly accurate and timely. Consequently, the exchange of information did not significantly affect the trust in retailers because trust is mostly built on previous experience of quality and fair collaboration. Producers bear the risks of production, payments, and infrastructure investments, and retailers are not willing to share these risks with them. They receive no support in terms of infrastructure, as retailers do not provide logistic infrastructure (e.g., transport, cooler storage, and warehouse space). The development of infrastructure (warehouses, cold stores, packaging plants, processing plants, etc.) is crucial for better long-term collaboration. In their studies, Lu et al. [102] and Uddin [93] argued that mutual investment can activate the buyer-seller relationship, enhance business transactions, and improve SC efficiency and performance. Additionally, retailers do not exchange information about the retail prices and margins that they define, and the latter may vary from 10 to $40 \%$. They very rarely work on joint promotion, although producers point out that the best promotion for them is word of mouth, which is achieved through direct sales and direct contact with consumers. According to research by Callado and Jack [103], customer satisfaction, not financial sustainability, is the driver of collaboration between SC partners and one of the important indicators of SC success. Alternatively, while retailers share information on sales and demand for the products, they do not inform the producers on customer needs and satisfaction. This is unfortunate, as it is very important for the organic SC to achieve greater communication with consumers due to the development of the organic market. Collaborative integration between actors in organic SCs is an opportunity for exchanging information, expanding knowledge, and solving problems together. Farmers have to deepen their knowledge and skills regarding production technology, market conditions (e.g., new forms of sales and distribution channels and promotional activities), and formal and legal procedures, and strengthen their competitive advantage over other market participants [95]. Networking with the various actors in the organic food sector is recommended, especially with the retailers.

Our research results indicate that both categories of organic food producers are mainly satisfied with the quality of the relationship that they accomplish with the retailers who mostly fulfil their expectations. They are very committed to a quality relationship and collaboration with their retailers. Producers have been improving their collaboration with the retailers who are more aware and for whom the offer of organic products is important. These are mostly small or specialized retailers who are much more flexible, and their 
relationships are more based on interpersonal trust. It is necessary to enhance quantity planning so that producers do not encounter problems with surpluses or shortages of production. On the other hand, collaboration and relationships with large retailers are not guaranteed nor permanent and are mostly purely business relationships and not friendships. Organic food producers are not completely satisfied with the prices that their products attain; however, price satisfaction does not seem to have the strongest impact, which is consistent with the findings of [44].

Both categories of organic food producers deem that their buyers have a good reputation in the market, which can significantly affect their performance and recognition of their product with consumers. When farmers believe that a buyer will be more successful in the long run, they consider the quality of the relationship more favourable [44]. In addition, the results of a study by Mesić et al. [20] confirm the positive and significant influence of reputation on SC performance. Retailers, apart from the specialized ones, do not know enough about the specifics of organic production, nor do they promote the advantages of organic products enough. All organic producers agree that trust, reliability, and safety depend hugely on the quality of the product. After years of collaboration and continuity in quality, personal trust (xinyong) develops close relationships (guanxi) between the actors. The findings of a study by Lobo et al. [29] suggest that xinyong is the key mediator between guanxi and the supplier's loyalty to the buyer and financial performance. Satisfaction has a positive effect on the farmers' commitment. The positive impact of satisfaction on commitment supports a study by Sahara and Gyau [97]. Farmers feel satisfied when their buyers provide favourable economic rewards (e.g., offer satisfactory prices), when the farmers' expectation of what they should receive has been met, and when their buyers quickly respond to their complaints.

The results of this study show that larger Category 1 producers are investing more effort into developing long-term collaborations. For them, this sales channel is important because they sell about $50 \%$ of their products through retailers. However, Category 2 producers are smaller and they collaborate less with retailers. It could be concluded that they are still developing relationships with their retailers. Insufficient production is currently the biggest obstacle to product placement through retail channels and, consequently, the development of long-term collaboration. It would be important for organic producers to develop collaboration with specialized retailers where consumers of organic products gravitate. For small producers, sales through retailers would be more important outside their area, i.e., all over Croatia, because direct sales are a simpler and more acceptable distribution channel for reaching the nearby consumers.

Organic food producers believe that long-term collaboration also tends to be hindered by the retailers' high margins, which make their products inaccessibly expensive in stores. Therefore, they consider trust as the basis for the development of long-term collaboration. Recent research, as well as this study, has confirmed that trust is important in developing long-term collaboration between farmers and retailers and an important driver of integration and collaboration within food SCs, which is contrary to previous research [104-107]. For example, Dapiran and Hogarth-Scott [106], in their study of food retail in the UK and Australia, argue that collaboration and trust are not the same; Hogarth-Scott [105] believes that power is the functional equivalent of trust, producing the same outcome, and collaboration is the result.

According to research by Sun et al. [58], suppliers perceive high levels of distributive fairness if they sell their products at satisfying prices. The procurement prices offered by the retailers and the prices at which they sell the products to the consumers are the key factors for distributing the common incomes of the AFSCs and are also connected to the suppliers' profits. The results of this research have revealed that procedural fairness has a strong positive effect on trust and commitment. The greater the level of trust among the chain actors, the higher the probability for the development of long-term collaboration [108]. As the satisfaction of farmers increases so does trust, which leads to long-term commitment to the relationship [57]. Willingness to collaborate affects trust and vice versa [96]. Trust 
fosters long-term relationships [38], reduces opportunistic behaviour [65], and increases the competitiveness and the performance of SCs.

Dependence on the retailer is more pronounced with larger producers, which is associated with higher production volumes and higher product placement through retailers, as well as with the quality and type of products (fresh or processed). High-level dependence might lead to uncertainties and opportunistic behaviours, resulting in conflicts that may negatively affect the overall collaboration and performance [109]. Producers who have high-quality products, especially processed products (e.g., olive or pumpkin oil), also have greater bargaining power, especially with regard to negotiating prices. The fact is that small farmers who are highly disorganized and lack support in infrastructure have a weak bargaining power $[72,110]$. However, the findings show that low bargaining power is not a problem for them at present as they do not depend on the retailers who are only an additional sales channel. For them, direct sales are more acceptable because they can dictate the prices of their products.

Retailers, on the other hand, form prices that are often much higher than those that the producers can achieve by direct sales. The growing bargaining power in the retailer sector seems to have a major influence in setting the product prices and distribution of margins within the chain [93]. The use of power can reduce the quality of the relationship, which then affects the operational efficiency of the supplier [54]. On the other hand, in their study, Kottila and Rönni [48] found that neither power imbalance nor difference of values form insuperable obstacles to the establishment of collaborative relationships in organic food chains and that quality communication is necessary for the creation of trust.

Trust is a crucial element in the AFSC due to the characteristics of food products, some of which may only be analysed after consumption, such as experience characteristics, and some may not be examined at all, such as credence characteristics [93]. The results of this study show that organic food producers trust their retailers quite entirely. Their trust is based on good past collaboration and good reputation of the retailer. Furthermore, trust and loyalty are more pronounced in relation to larger organic food producers and specialized organic food retailers. Organic food producers believe in the expertise, honest advice, and information that the retailers share with them. However, they believe that personal trust has not yet developed between them (xinyong), which is associated with honesty, credibility, reputation, and integrity of an individual based on a gentleman's word [29]. The results of this study showed that, in addition to giving organic food producers better bargaining power, they also influence the development of trust between producers and retailers. In other words, a product that shows good potential in the market involves a minor economic risk for the retailer. This enables the development of trust in the product and more generally in the producers supplying the product [75].

Literature shows diverse antecedents or determinants of trust in AFSCs $[43,44,52,77]$ and the importance of developing trust for AFSC performance. However, some previous research indicates a lack of trust among stakeholders in organic SCs, e.g., due to problematic information flow within the SC [101], lack of trust caused by lack of quality communication which particularly affects the personal and process dimension of trust [48], low perceptions of organic food producers' trust in retailers who rely more on the contractual relationship than on trust as a prerequisite for good collaboration [93], etc. However, this research confirmed that a number of preconditions for the development of trust have been met between organic farmers and retailers, such as relationship satisfaction, contractual relationship with specialized retailers, quality of communication achieved through frequent communication, joint problem solving, partner reputation, flexibility in the relationship, reliability, goodwill, commitment, and positive past collaboration. On the other hand, the following preconditions for the development of trust and quality collaboration have not been fully met: credibility of information, reliability of promises, goal compatibility and investments, price transparency, price satisfaction, and personal trust.

Due to the specifics of AFSCs and the characteristics that distinguish them from other SCs, it is difficult to measure their performance [103]. Performance indicators of AFSCs are 
grouped into four main categories that contain financial and non-financial performance indicators [78,111,112]: efficiency, flexibility, responsiveness, and food quality. Each of these main categories contains several different performance indicators. Efficiency measures the optimal use of resources in the SC and aims to maximize the added value of the process and minimize costs. Flexibility is the ability to adapt to a changing environment, and can be measured, for example, through flexibility in delivery or customer satisfaction. Responsiveness is the speed at which the SC delivers products to the customer. Food quality and food safety are special characteristics of food SCs that imply the quality of products and processes. The results of this study show that collaboration with the retailers affects the financial performance of the larger Category 1 producers, which is reflected in higher profits and competitiveness based on the ability to sell at lower prices than the competition and a partial reduction in costs. The results of the study by Naspetti et al. [55] also show that in organic SCs, greater trust results in greater collaboration, which in turn will result in greater non-financial and financial impacts whereby the effect of trust on financial performance is not direct but mediated by higher collaboration. Effective collaboration with specialised retailers has contributed to the professionalism of larger organic food producers, especially in terms of standardization and food quality. This is in contrast to the findings of Naspetti et al. [55], which indicate that there is no evidence that collaboration actually improves product quality and safety in organic food SCs. Contractual collaboration with the retailers contributes to production expansion, better production planning, and affects the expansion of family farms and employment. In their research, Bandara et al. [54] found that RQ and collaboration performance are positively related to the supplier's operating results. However, the problem occurs with large retailers who offer more European and well-known brands that are more recognizable to the consumers, which results in the Croatian products often being 'lost' on the shelves. In addition, sales to large retailers are not safe for the producers because the contracts are not defined in advance in terms of quantity and time, which affects the certainty of production and sales for the producers.

Given that the volume of sales through the retailers for smaller organic food producers is significantly lower (maximum $20 \%$ of total sales), collaboration and trust cannot significantly affect their financial and non-financial performance indicators. They mainly sell to small retailers and often depend on their monthly or seasonal sales dynamics. Reliability and speed of delivery are based on the flexibility of producers and trust in retailers. In the research conducted by Lobo et al. [29], the authors confirmed that collaboration with the customer based on informal relationships and personal trust can significantly affect the loyalty and financial performance of suppliers. Collaboration with small retailers at the local and regional levels is considered successful, especially regarding fresh products (short SC). However, this sales channel is not crucial for them as it does not significantly affect their revenues and their competitiveness. They are more oriented towards direct sales where they achieve better interaction and communication with the end consumers, higher prices for their products, and ultimately higher profits. Collaboration with the retailers could affect performance, if they had larger quantities of products and thus could expand in the market (they could go beyond the local and regional market). In addition, small producers often do not have developed sales skills due to their production-orientation, which means that selling through retailers can significantly facilitate their marketing and promotion and allow them more time for what they specialise in, i.e., production.

\section{Managerial Implications, Limitations, and Future Research Directions}

Given that this is the first time a study was conducted about the organic food producers perceptions of relationship quality with retailers in the organic food SC in Croatia, this research represents an important contribution to business practice. The results of this research can serve as an informative basis for all members of the SC by encouraging them to reach proactively to improve collaboration and trust, which can lead to overall performance improvements in the organic food SCs. 
However, this study also has some limitations. We collected data from only six different organic food producers, in terms of their size, length of collaboration with retailers, share of sales through different distribution channels, and different product types (fresh or processed), to investigate the SC relationships between organic food producers and retailers. Although such small sample sizes are not unusual in AFSC research, especially as they provide deeper insights into problems and potential solutions, future research can expand this body of knowledge by including larger samples.

As one of the aims of this research was to explain the experience and attitudes about their relationships with retailers of two essentially different organic food producer groups, we believe this research is relevant and timely. Given that snowball techniques were used in this study [92], and data on retailers with which organic food producers cooperate were obtained, in the next research phase, we suggest including the same organic food producers as well as retailers [90], in order to gain insight into attitudes of the other side in this SC, where retailers can be grouped into specialized, small retail, and retail chains (large). Additionally, based on this preliminary research study, a quantitative approach could be used in future research on a larger sample of organic food producers, using structural equation modelling or some other quantitative analysis technique. In future research, this conceptual idea and model should be applied to both organic food producers and retailers.

\section{Conclusions}

Due to the differences in product characteristics (i.e., fresh or processed food), there are different relationship structures (e.g., farmer-processor, farmer-retailer, processorretailer, etc.) or forms of management in the AFSC that significantly affect the quality of collaboration and relationships. In the case of the relationship between farmers and retailers in the AFSC, both business relationships (e.g., prices, costs, and the market) and social relationships (e.g., local connections, trust, and friendship) are considered important to the overall success of the AFSC.

Collaboration is vital for the empowerment of small farmers, especially those in communities with low socio-economic status. As key stakeholders in the AFSC, farmers typically have limitations in market business skills, aspirations, and systematic thinking; thus, they often focus heavily on their business rather than creating an integrated system of collaboration with retailers. Conflicts and misunderstandings can be minimized by understanding and managing the essential factors of quality collaboration in the partnership of farmers and retailers. Close collaboration can help reduce business uncertainty and risk and achieve better performance for each stakeholder individually and throughout the chain. To achieve this, it is necessary to achieve certain prerequisites for quality collaboration between farmers and retailers, such as quality, frequent and open communication, sharing information on business performance, knowledge and risk sharing, high quality relationships that include reliability, honesty, good faith, mutual respect, and the inevitable mutual trust and joint efforts to improve relations and long-term collaboration.

This empirical qualitative study was conducted on a sample of organic food producers in Croatia from March to August 2021. The research results indicate that organic food producers mostly have short SCs, and the fact is there is no real SC (there are not enough requirements for monitoring traceability, sharing common risks, developing new products, joint investments or parts of resources, common plans and goals, etc.). With respect to the organic food producers, the second category of producers (smaller producers) do not depend on retailers because the share of sales through this channel is small for them (maximum 20\%). There is high uncertainty of collaboration with large retail chains for both categories of organic food producers, while collaboration with small retailers is often informal and based on interpersonal trust. Quality relationships and collaboration also depend significantly on the quality of products offered by organic food producers. Specialized retailers set higher quality requirements, while small ones do not. Among organic food producers and retailers, mostly only market information (legislation and market requirements) is shared. The retailer is not interested in information about organic 
production and the problems of organic producers; thus, they are poorly acquainted with the operational activities of organic food producers. Dependence on retailers is conditioned by the amount of production and the type of product (fresh or processed). The retailer has more, but not full, bargaining power, especially when it comes to organic producers of processed products. The quality of collaboration and trust is higher in the first category of organic food producers, and in the second category in the situation where personal relationships develop, i.e., interpersonal collaboration with the retailer. The perception of the impact of collaboration and trust on overall performance is completely different in the first and second category of producers. All organic producers recognize the same problems in the market of organic products and give similar recommendations for the development of the organic food market.

This study is an original empirical contribution to the organic food SC literature with an emphasis on RQ. Our empirical study provides deeper insights into the perceptions of small and medium organic food producers about the factors of collaboration and trust, and their impact on producer and chain performance as a whole. This paper contributes to an identified gap in the literature by presenting new insights into asymmetric producerretailer relations from a perspective that has not previously been adequately researched in organic food SC management studies. At the same time, this is the first study that examines the relationship between producers and retailers of organic food in Croatia, to which not enough attention was so far dedicated, despite their potential importance for further development of the organic food market.

Author Contributions: Conceptualization, D.G., Ž.M. and K.P.; methodology: D.G. and K.P.; formal analysis, D.G., Ž.M. and K.P.; investigation, D.G.; resources; writing-original draft preparation, D.G. and K.P.; writing—review and editing, D.G., Ž.M. and K.P; visualization, D.G.; supervision, K.P. All authors have read and agreed to the published version of the manuscript.

Funding: This research received no external funding.

Institutional Review Board Statement: The study was conducted according to the guidelines of the Declaration of Helsinki, and approved by Ethics Committee of Faculty of Economics and Business, University of Rijeka (Ethical standards stipulated in the University of Rijeka Code of Ethics, Rijeka, 5 October 2020).

Informed Consent Statement: Informed consent was obtained from all subjects involved in the study.

Acknowledgments: The authors would like to thank two anonymous reviewers for their valuable comments helping them improve the paper. They would like to express their sincere gratitude to the organic food producers who participated in the explorative research.

Conflicts of Interest: The authors declare no conflict of interest.

\section{Appendix A. Interview Remainder for Organic Food Producer}

QUESTIONS FOR IN-DEPTH INTERVIEW OF ORGANIC AGRI-FOOD PRODUCERS

\section{The criteria for selecting the producers to be interviewed:}

1. Minimum 3 years active business operation in the market, i.e., selling to retailers.

2. Equal distribution of the number of respondents regarding the type of product (fruit, vegetables, meat and meat products, milk and dairy products, finished products, e.g., honey).

3. Minimum of six interviewees, preferably ten.

Interview guide will be conducted on the basis of four topics/areas. At the beginning, please give us some information on yourself and your family farm.

PART 1: Structural features of the production unit

1. Producer's name: (Please complete) 
2. Year of registration into Eco Registry: (Please complete)

3. County where the production unit is located: (Please fill in)

4. How old are you? (Please write)

5. Interviewee's gender: (please circle) $\mathbf{M} \check{Z}$

6. What is your highest level of education or training successfully completed?

(a) Incomplete primary school.

(b) Complete primary school.

(c) Completed secondary school.

(d) Competed short-cycle tertiary education or bachelor's degree.

(e) Master's degree or PhD degree.

7. What is the legal status of your farm? (Please circle):

(a) Family farm.

b) Family farm in VAT system.

(c) Sole proprietorship.

(d) Company.

(e) Cooperative.

(f) Other (please specify):

8. What is the total area (in ha) of your farm as registered in ARKOD? (Please state):

\section{What type of farm do you come from?}

a. Agricultural (the family lives exclusively from agriculture).

b. Mixed (in addition to agriculture, at least one member is employed elsewhere).

10. Who works at the farm? (Please circle and fill in the blanks if necessary)

a. My family and I (please, state the number):

b. Permanent employees (please, state the number):

c. Seasonal workers (please, state the number):

11. Please state the key motive for practicing organic agriculture. (Please circle only one answer):

(a) Personal views.

(b) Health reasons.

c) Financial reasons only.

(d) Government incentives.

(e) Environmental protection.

(f) Influence of acquaintances and eco associations.

(g) Self-employment.

(h) Unemployment.

(i) Other (please state what): 
12. Please state all activities that your farm is registered for (you can circle more than one answer, e.g., (a) Producer A-A1 Plant Production and (f) Processing B).
(a) Producer A-A1 Plant Production.
(b) Producer A-A2 Cattle Breeding.
(c) Producer A-A3 Mixed production.
(d) Producer A-A4 Collecting Wild Plants.
(e) Producer A-A5 Apiculture.
(f) Processing B.
(g) Importer $\mathrm{C}$.
(h) Exporter D.
(i) Distributer/Trader/Retailer E.
(j) Other (please specify):

13. Please state what type of agricultural activity you are involved in: (circle one or more answers)

(a) Cultivation of arable crops.

(b) Cultivation of vegetables.

(c) Cultivation of fruit crops.

(d) Viniculture.

e) Medicinal and culinary herbs.

(f) Forage plants.

(g) Apiculture.

(h) Animal husbandry.

(i) Other: (please specify)

14. If you cultivate vegetables, please specify the VEGETABLE(S) you produce: (circle one or more answers)

- $\quad$ Sweet potato.

- Chard.

- Bob.

- Broccoli.

- Pumpkin/squash.

- Celery.

- Beet root.

- Cauliflower.

- Garlic.

- Melons.

- Peas.

- Mushrooms.

- Horseradish

- Kale.

- Cucumbers.

- Potatoes.

- Cabbage.

- Watermelons.

- Onions.

- Carrots.

- Paprika.

- Eggplant.

- Parsley.

- Leek.

- Tomato.

- Radish.

- Salad.

- Asparagus.

- Spinach.

- Pumpkin, zucchini. 
Other (please specify):

15. If you cultivate fruits, please specify the FRUIT(S) you produce: (circle one or more answers)

- Aronia.

- Elderberries.

- Blueberries.

- Peaches.

- Goji.

- Apples.

- Strawberries.

- Chestnuts.

- Pears.

- Blackberries.

- Hazelnuts.

- Raspberries.

- Apricots.

- Gooseberries.

- Walnuts.

- Currants.

- Figs.

- Pomegranates.

- Plums.

- Cherries.

- Sour cherries.

- Grapes.

- Other (please specify):

16. If you breed animals, please specify the ANIMAL(S) you produce: (circle one or more answers)

- Cattle breeding.

- Pig breeding.

- Goat breeding.

- Sheep breeding.

- Horse breeding.

- Chickens.

- Turkey/duck/goose.

- Dairy cows.

- Other (please specify):

17. If you are processing primary agricultural produce:

(a) Yes (question 18)

(b) No (part 2).

18. If your answer to the previous question is YES, please specify the products: (circle one or more answers)

- $\quad$ Preserved produce (e.g., vegetables, fruit, and their preserves) (please specify):

- $\quad$ Frozen produce (e.g., vegetables, fruit, meat, fish, etc.) (please specify):

- $\quad$ Dried produce (e.g., vegetables, fruit, etc.) (please specify): 
- Meat and processed meat products; fresh, refrigerated, dried, etc. (e.g., sausages, salamis, dried and smoked meat) (please specify):

- $\quad$ Fish and processed fish products (e.g., tins, dried fish etc.) (please specify):

- $\quad$ Fats and oils (please specify):

- Vinegar, different kinds (please specify):

- Juices and other non-alcoholic drinks and beverages (please specify):

- Alcoholic drinks (please specify):

- Flours, various (please specify):

- Bread and other bakery products (please specify):

- Cereal products, e.g., buckwheat, barley, millet, turmeric, bulgur, quinoa, couscous (please specify):

- Cakes, biscuits, and other confectionery products (please specify):

- Pasta (e.g., dried, frozen, etc.) (please specify):

- Milk and dairy products (e.g., yogurts, creams, cheeses, butter, etc.) (please specify):

- Cocoa and other derivatives from cocoa (please specify):

- $\quad$ Coffee (please specify):

- Teas and herb infusions (please specify):

- Honey and honey products (please specify):

- Culinary herbs and spices (please specify):

- Sauces, various (please specify):

- Sugars, various (please specify):

- Nut products (please specify): 
- Other (please specify):

PART 2: Market and distribution of agri-food products

Now we would like to find out more about the methods and locations of your product sales.

1. Please mark in the table (with an $\mathrm{X}$ ) where you sell your products (locally, regionally, nationally), the method of selling, and the share of each method in your total sales (approximately in \%) (you may choose more than one answer combination).

\begin{tabular}{|c|c|c|c|c|c|c|}
\hline \multirow[b]{2}{*}{ Sales Method } & \multicolumn{6}{|c|}{ Geographic Location of Market } \\
\hline & $\begin{array}{l}\text { Locally (up to } \\
50 \mathrm{~km} \text { ) }\end{array}$ & $\%$ & $\begin{array}{c}\text { Regionally } \\
\text { (More than } 50 \text { km) }\end{array}$ & $\%$ & $\begin{array}{l}\text { Nationally (Entire } \\
\text { Territory of Croatia) }\end{array}$ & $\%$ \\
\hline \multicolumn{7}{|l|}{ At family farm } \\
\hline \multicolumn{7}{|l|}{ At local market } \\
\hline \multicolumn{7}{|l|}{ At other markets } \\
\hline \multicolumn{7}{|l|}{ Home delivery } \\
\hline \multicolumn{7}{|l|}{ Specialised fairs } \\
\hline \multicolumn{7}{|l|}{ Special events (e.g., Fruit Days) } \\
\hline \multicolumn{7}{|l|}{ Internet sales } \\
\hline \multicolumn{7}{|l|}{$\begin{array}{l}\text { Vending machines } \\
\text { (e.g., milk machine) }\end{array}$} \\
\hline \multicolumn{7}{|l|}{ Caterers (hotels, restaurants, cafés) } \\
\hline \multicolumn{7}{|l|}{ Patisseries, bakeries, etc. } \\
\hline \multicolumn{7}{|l|}{ Agri-tourism farms } \\
\hline \multicolumn{7}{|l|}{ Corner shops (e.g., small shops) } \\
\hline \multicolumn{7}{|l|}{ Specialised retailers (e.g., Bio\&Bio) } \\
\hline \multicolumn{7}{|l|}{$\begin{array}{l}\text { Retail chains (supermarkets, etc., e.g., } \\
\text { Konzum, Kaufland ... ) }\end{array}$} \\
\hline \multicolumn{7}{|l|}{ Processing companies (e.g., Podravka) } \\
\hline \multicolumn{7}{|l|}{ Purchasers } \\
\hline \multicolumn{7}{|l|}{$\begin{array}{l}\text { Public, government institutions } \\
\text { (e.g., hospitals, schools) }\end{array}$} \\
\hline Other (please specify) & & & & & & \\
\hline
\end{tabular}

2. Please explain why you distribute your products through this specific method and specify the products. 
3. Please state what sales method is more cost-efficient for your products (on a scale: 1-not at all, 2-insufficiently profitable, 3-profitable, 4-very profitable, 5-extremely profitable)

\begin{tabular}{cllll}
\hline Sales Method & $\mathbf{1}$ & $\mathbf{2}$ & $\mathbf{3}$ & $\mathbf{4}$ \\
\hline As a primary agricultural product & & & & \\
\hline As raw material for processing & & & \\
\hline As processed (finished) product & \\
\hline Other (please specify)
\end{tabular}

4. Please state THREE KEY ORGANIC PRODUCTS that you sell annually; mark with an $\mathrm{X}$ in the table the sales method (direct sales and/or through intermediary, i.e., salesperson); then state approximate quantities of sales (e.g., in kilograms, litres, etc.).

Type of Organic Product Sales Method and Quantity Sold (in kg., 1, etc.)

Direct Sales Quantity Retailer Quantity

5. In which counties do you sell your products through an intermediary/trader? (Please circle)
(a) Bjelovar-Bilogora.
(b) Brod-Posavina.
(c) Dubrovnik-Neretva.
(d) City of Zagreb.
(e) Istria.
(f) Karlovac.
(g) Koprivnica-Križevci.
(h) Krapina-Zagorje.
(i) Lika-Senj.
(j) Međimurje.
(k) Osijek-Baranja.
(l) Požega-Slavonia.
(m) Primorje-Gorski Kotar.
(n) Sisak-Moslavina.
(o) Split-Dalmatia.
(p) Šibenik-Knin.
(q) Varaždin.
(r) Virovitica-Podravina.
(s) Vukovar-Syrmia.
(t) Zadarska.
(u) Zagreb County. 
6. Please enter which trader and how long you have been selling your products, as well as the types of products and where they can be purchased.

Type of Organic Product

Trader

Duration of Collaboration (Years)
Location of Purchase (Split, Zagreb, Osijek, etc.)

7. Do you believe that it would be easier to sell your produce as processed products? Please explain (why yes, why no).

PART 3: Relations between producers and retailers of organic food products. Proposals for developing partnerships. COLLABORATION-TRUST-PERFORMANCE

(A) INTER-ORGANISATIONAL COLLABORATION (trustworthiness, collaboration, positive past collaboration, etc.).

1. Please, describe briefly what it is like and what the basic characteristics of your collaboration with the retailers are. Inter-organisational collaboration (collaboration with retailer, type of collaboration, contractual or not, etc.)

2. Please evaluate the degree of agreement with the statements that relate to the inter-organisational collaboration, marking 1-5: 1-totally disagree, 2-do not agree, 3-neither agree nor disagree, 4-agree, 5-totally agree.

\section{Statement}

1. Collaboration with the retailer is of huge importance for my farm.

2. I am satisfied with the collaboration with my retailer.

3. My farm recognises the importance of collaboration with the retailers for easier sales.

4. My collaboration with the retailer is contractual, which suits me entirely.

5. We do not have a strictly defined contract with the retailer, which suits me entirely.

6. I do not intend to change my retailer in the future.

7. My retailer is not interested in the quality of my products.

8. My retailer made sacrifices in the past.

9. Trading with my retailer is less risky for my business operation.

10. I do not care who my retailer is, as long as I am satisfied with the product price. 
11. My retailer always considers the best interests of both sides.

12. We have issues regarding product delivery with the retailer due to frequent changes in orders.

13. We have clearly defined terms of delivery, payment, etc. with the retailer.

(B) QUALITY OF COMMUNICATION (frequency, volume, quality, satisfaction with communication, etc.).

1. Please describe briefly, what it looks like and what the basic features of your communication with the retailer are. How would you qualify the quality of that communication?

2. Please evaluate the degree of agreement with the statements referring to communication with the retailer, marking 1-5: 1-totally disagree, 2-do not agree, 3-neither agree nor disagree, 4-agree, 5-totally agree.

\section{Statement}

$\begin{array}{lllll}1 & 2 & 3 & 4 & 5\end{array}$

1. My retailer and I mostly communicate indirectly (on-line etc.).

2. I find it important that my retailer and I communicate face to face as often as possible.

3. Communication with our retailer is mostly formal.

4. Communication with our retailer is often informal.

5. My retailer is always open and ready for communication.

6. Communication with my retailer is high quality (open, frank).

7. Communication with the retailer reflects positively on the performance of our collaboration.

\section{(C) INFORMATION, RISK, KNOWLEDGE, AND RESOURCE SHARING (trans- parency among partners etc.).}

1. Please, describe briefly the basic features of sharing information between you and your retailer and what it looks like. What information do you share? Do you share business risks, information, and resources?

2. Please evaluate the degree of agreement with the statements referring to the exchange of information, risks, information, and resources with your buyer, marking 1-5: 1-totally disagree, 2-do not agree, 3-neither agree nor disagree, 4-agree, 5-totally agree.

\section{Statement}

$\begin{array}{lllll}1 & 2 & 3 & 4 & 5\end{array}$

1. My retailer is ready to share risks with me.

2. My retailer shares with me information and experience.

3. I receive all necessary information from my retailer in due time.

4. My retailer does not inform me on the changes in business operations, etc.

5. My retailer's advice helps me improve production practice.

6. I have insufficient information on important issues for quality of business relation with our retailer. 
7. My retailer shares all information that could help me in my business operations.

8. We regularly exchange information on business activities and changes that may impact our business operations.

9. My retailer and I exchange feedback on business performance.

10. I believe that sharing information with the retailer can improve operational efficiency.

11. I believe that sharing information with retailer may improve financial performance of both partners.

12. Our retailer shares information on sales and demand for the product/s.

13. My retailer regularly informs us on customer needs and satisfaction.

14. My retailer provides us with the logistic infrastructure (transport, cooler storage, warehouse).

15. My retailer offers timely information on the changes of her/his retail prices.

16. Information on prices offered by retailers is complete, correct, and transparent.

17. My retailer and I plan, communicate information, and carry out promotional activities together.

18. My retailer offers me financial support if I need it.

(D) RELATIONSHIP QUALITY AND COMMITMENT (personal ties, integrity, benevolence, etc.).

1. How would you describe the quality of your relationship with the retailer? Interpersonal level (mutual respect, friendship, welfare, problem solving, etc.).

2. Please evaluate the degree of agreement with the statements referring to the quality of relationship with your buyer, marking 1-5: 1-totally disagree, 2-do not agree, 3-neither agree nor disagree, 4-agree, 5-totally agree.

\section{Statement}

$\begin{array}{lllll}1 & 2 & 3 & 4 & 5\end{array}$

1. My retailer mostly fulfils my expectations.

2. My retailer is very trustworthy.

3. My retailer reacts fast to my objections and solves complaints.

4. I am happy with the price that my retailer pays for my product.

5. My retailer knows the specifics of our products well (e.g., nutritive qualities, methods of production, etc.) and uses them in promotion.

6. In the case of a product delivery problem, my retailer always shows understanding.

7. We are very committed to quality relationship and collaboration with our retailer.

8. I have realised very close friendship with my retailer. 
9. In case of a problem, my retailer will see to it that it does not threaten our contractual relationship.

10. Problems and disagreements with the retailer are often solved informally.

11. Problems and disagreements with the retailer are solved quickly.

12. I plan to cooperate with my retailer in the future as well.

13. Although I have an alternative buyer, I'll keep selling to my buyer.

14. I am loyal to my retailer.

15. My retailer shows understanding for my problems regarding agricultural production.

16. Disagreements between my retailer and me are rare.

\section{(E) LONG-TERM ORIENTATION (joint plans and interests).}

1. How do you feel about the future with your buyer?

2. Please evaluate the degree of agreement with the statements that refer to long term business operations with your retailer, marking 1-5: 1-totally disagree, 2-do not agree, 3-neither agree nor disagree, 4-agree, 5-totally agree.

\section{Statement}

$\begin{array}{lllll}1 & 2 & 3 & 4 & 5\end{array}$

1. My retailer and I aspire to long-term business operation.

2. I often discuss mutual expectations with my retailer.

3. My retailer and I continuously work on improving long-term collaboration.

4. I expect this retailer to do business with me for a long time in the future.

5. My retailer and I are working together on planning future demand.

6. Both parties invest significant efforts in building quality long-term relations.

7. I expect to cooperate more intensively with my retailer in the future.

8. We invest maximum efforts in keeping a quality relationship with our retailer.

\section{(F) POWER/DEPENDENCE/OPPORTUNISM (all depend on trust).}

1. Please give details about your relationship with the retailer (setting terms, domination, negotiating power, etc.). Do you believe that the size of your farm (production volume) can or does significantly impact your negotiating power?

2. Please evaluate the degree of agreement with the statements that refer to the relationship with your retailer, marking 1-5: 1-totally disagree, 2-do not agree, 3-neither agree nor disagree, 4-agree, 5-totally agree. 


\section{Statement}

$\begin{array}{lllll}1 & 2 & 3 & 4 & 5\end{array}$

1. This retailer is crucial for my business performance.

2. I can choose a different retailer at any moment.

3. My retailer relies on me as supplier.

4. I do not depend on this retailer, although s/he has capacity and ability to purchase all our products.

5. I strictly have to adhere to the demands of my retailer.

6. If I did not have a long-term contract, I would switch to another retailer.

7. My retailer has total power in the supply chain.

8. My retailer does not accept/respect my business attitude and tradition.

9. My retailer mostly follows only her/his interests, i.e., acts opportunistically.

10. I am getting more and more dependent on my retailer.

11. My retailer has total power in my production and product purchase.

12. In order to realise her/his aims, my retailer sometimes alters facts (distorts reality).

13. We have no alternative buyer.

\section{(G) TRUST (loyalty/fidelity).}

1. Do you believe that you are loyal to your retailer and that you have developed a relationship of trust? Can you say a bit more about it?

2. Please evaluate the degree of agreement with the statements referring to trust with your retailer, marking 1-5: 1-totally disagree, 2-do not agree, 3-neither agree nor disagree, 4-agree, 5-totally agree.

\begin{tabular}{lllllll}
\hline Statement & 1 & 2 & 3 & 4 & 5
\end{tabular}

1. My retailer always keeps her/his promises.

2. My retailer never makes false claims.

3. I trust earnest advice of my retailer.

4. I trust the data and information that my retailer shares with me.

5. I would recommend other farmers to become suppliers for my retailer.

6. From my long-standing experience, I know I can trust my retailer.

7. Even if something goes wrong, I will remain loyal to my retailer.

8. I trust my buyer's expertise.

9. I totally trust my retailer. 
10. My retailer ensures high integrity supply chain of organic agri-food products.

11. My retailer treats me fairly and justly.

12. My retailer has good reputation on the market, i.e., with the consumers.

(H) OVERALL PERFORMANCE OF SUPPLY CHAIN (efficiency and performance of business operations, individual, and the entire supply chain, support among chain members, mutual benefits, etc.).

1. How do you measure the performance of your collaboration (by quantity of sold products or some other way)? How do you think the collaboration with your buyer influences the performance? Do you believe that collaboration with your buyer affects the performance of the supply chain and what indicators illustrate this?

2. Please evaluate the performance of the supply chain that you are a member of, which is based on the previously evaluated collaboration and trust quality factors, marking 1-5: 1-not improved at all, 2-improved, 3-I don't know, 4-improved, 5-improved significantly.

-Quantitative business operations indicators.

As a Result of Collaboration and Trust with Our Buyer the Following Has Been Noticed:

Improvement of business processes (coordination and optimisation).

Operational efficiency-e.g., optimal use of resources in OL, optimisation of stocks, etc.

Reliability and speed of delivery.

Planning demand.

Reduction in total costs for both sides, e.g., logistical.

Flexibility in delivery volumes (e.g.).

Time between sending the order and delivery.

Speedy dealing with complaints-implying answering them.

Buyer and end consumer satisfaction.

We make higher profits.

I have achieved a better competitive advantage on the market.

We are able to offer low prices and even lower than the competitors'.

Decline in opportunistic behaviour (e.g., more mutual respect, work for benefit of both parties).

The quality of my products has increased.

Communication between us has increased.

We consider realising mutual benefits in business operations.

Reduced risks for both parties.

Reduction/optimisation of stocks.

Introduction and/or improvement of online retailing.

PART 4: Proposals for market development

Please, give your proposals for the future development of organic agri-food product supply chains in general. Do you have a proposition on how to develop collaboration and markets for organic agri-food products? 


\section{Appendix B}

Table A1. Similarities and differences in the perceptions of the first and second category of organic food producers.

\begin{tabular}{|c|c|c|c|}
\hline \multirow[b]{2}{*}{ Metrics for Collaboration Items } & \multirow{2}{*}{$\begin{array}{c}\text { SIMILARITIES } \\
\begin{array}{c}\text { 1st and 2nd Group of Organic } \\
\text { Food Producers }\end{array}\end{array}$} & \multicolumn{2}{|c|}{ DIFFERENCES } \\
\hline & & $\begin{array}{l}\text { 1st Group of Organic } \\
\text { Food Producers }\end{array}$ & $\begin{array}{l}\text { 2nd Group of Organic } \\
\text { Food Producers }\end{array}$ \\
\hline $\begin{array}{l}\text { INTER-ORGANISATIONAL } \\
\text { COLLABORATION } \\
\text { (type of collaboration, } \\
\text { formal/informal, reliability, } \\
\text { positive past collaboration) }\end{array}$ & 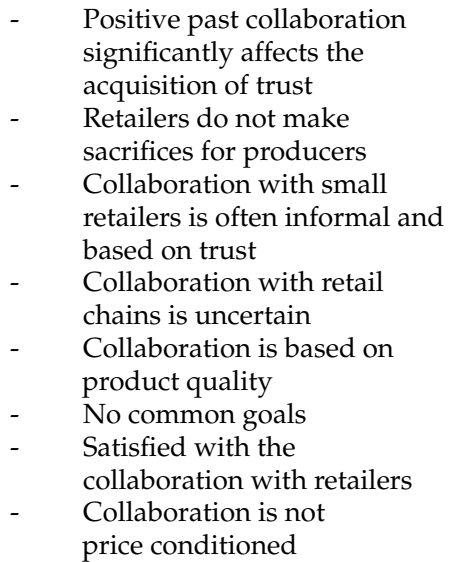 & $\begin{array}{ll}\text { - } & \text { Collaboration is } \\
\text { formal/contractual } \\
\text { - }\end{array} \begin{array}{l}\text { Clearly defined delivery } \\
\text { times and payment times } \\
\text { - } \quad \begin{array}{l}\text { Reliability } \\
\text { - }\end{array} \\
\begin{array}{l}\text { Uncertainty of } \\
\text { collaboration with retail } \\
\text { chains-contracts }\end{array} \\
\text { are undefined } \\
\text { - } \\
\text { There are surpluses } \\
\text { or deficits } \\
\text { - } \quad \begin{array}{l}\text { Risk and uncertainty } \\
\text { of production }\end{array} \\
\text { - } \quad \begin{array}{l}\text { Quality requirements- } \\
\text { strict standardization }\end{array}\end{array}$ & $\begin{array}{ll}\text { - } & \text { Orders have no } \\
\text { continuity-unreliability } & \text { Clearly defined delivery } \\
\text { - } & \text { and payment times } \\
\text { - } & \text { There is flexibility, } \\
\text { but not security for } \\
\text { planned production } \\
\text { - } \quad \begin{array}{l}\text { No dependence } \\
\text { on retailers }\end{array}\end{array}$ \\
\hline
\end{tabular}

QUALITY COMMUNICATION (frequency, quantity, quality, satisfaction)
Small retailers are less informed

First contacts are often established at eco-fairs Communication depends on the type of product (fresh or processed) and the season
Quality, open, and

frequent communication

Maintained on the success

of mutual collaboration

Timely and

dynamic-especially when

selling fresh products

Communication on a daily

basis, by phone or

by email

It is important to achieve

a personal face-to-face

communication
Not much communication (and even less online)

Informal collaboration also results in informal communication It does not significantly affect the success of joint collaboration
INFORMATION, RISK,

KNOWLEDGE, AND

RESOURCE SHARING

(transparency between partners)
Sharing information on market regulations

Sharing demand information Retailer does not inform the organic food producer about the changes in retail prices No sharing of information and knowledge about organic production

- $\quad$ Retailers are not interested in participating in the development of new product Customers mostly do not provide financial assistance No sharing of resources, such as warehousing, transportation etc. No perception or common sharing of production risk No sharing of business performance information
Retailer defined the price, the margins are very different (from 10 to $40 \%$ ), and did not share this information with organic food producers-no transparency Information on product quality is exchanged Sharing knowledge about market factors

There is no interest of the retailer to participate in the development of new product

The level of formality and frequency of information exchange depends on the type of retailer with whom it cooperates

Sometimes there is a joint promotion
There is not much communication, there is no exchange of information A more personalized relationship is established with small retailers-guanxi. There is a better interaction with small retailers in terms of demand information for our products Information that is important for the relationship quality Retailers do not provide financial assistance A joint promotion is rarely performed 
Table A1. Cont.

\begin{tabular}{|c|c|c|c|c|c|}
\hline \multirow[b]{2}{*}{ Metrics for Collaboration Items } & \multirow{2}{*}{$\begin{array}{c}\text { SIMILARITIES } \\
\text { 1st and 2nd Group of Organic } \\
\text { Food Producers }\end{array}$} & \multicolumn{4}{|c|}{ DIFFERENCES } \\
\hline & & & $\begin{array}{l}\text { 1st Group of Organic } \\
\text { Food Producers }\end{array}$ & & $\begin{array}{l}\text { 2nd Group of Organic } \\
\text { Food Producers }\end{array}$ \\
\hline $\begin{array}{l}\text { LONG-TERM ORIENTATION } \\
\text { (common plans and interests) }\end{array}$ & $\begin{array}{l}\text { We have no joint plans } \\
\text { There is no collaboration in } \\
\text { the development of } \\
\text { new products } \\
\text { Open for collaboration with } \\
\text { other retailers } \\
\text { They expect to collaborate } \\
\text { more intensively with retailer } \\
\text { in the future }\end{array}$ & - & $\begin{array}{l}\text { They are continuously } \\
\text { working on long-term } \\
\text { collaboration } \\
\text { Both sides invest } \\
\text { significant efforts in the } \\
\text { development of quality } \\
\text { long-term relations } \\
\text { They often discuss } \\
\text { mutual expectations } \\
\text { The retailer and I are } \\
\text { planning future } \\
\text { demand together }\end{array}$ & $\begin{array}{l}- \\
- \\
- \\
- \\
-\end{array}$ & $\begin{array}{l}\text { They do not work } \\
\text { continuously to improve } \\
\text { long-term collaboration } \\
\text { They do not depend on the } \\
\text { long-term orientation } \\
\text { They do not plan future } \\
\text { demand together } \\
\text { Dependence on } \\
\text { production volumes } \\
\text { Trust is the basis for } \\
\text { long-term collaboration } \\
\text { Negative impact of too } \\
\text { high margins on } \\
\text { long-term collaboration } \\
\text { They rarely discuss } \\
\text { mutual expectations }\end{array}$ \\
\hline
\end{tabular}

\begin{tabular}{|c|c|c|c|c|c|c|}
\hline $\begin{array}{l}\text { QUALITY OF RELATIONSHIP } \\
\text { (existence of personal } \\
\text { connections, honesty, goodwill, } \\
\text { customer reliability, mutual } \\
\text { respect, interpersonal } \\
\text { collaboration.) }\end{array}$ & $\begin{array}{r}- \\
- \\
- \\
- \\
- \\
- \\
- \\
- \\
- \\
-\end{array}$ & $\begin{array}{l}\text { Depends on the quality } \\
\text { of products } \\
\text { After many years of } \\
\text { collaboration, interpersonal } \\
\text { trust is developing (guanxi) } \\
\text { The relationship with retail } \\
\text { chains is not guaranteed } \\
\text { and permanent } \\
\text { Retailers are not sufficiently } \\
\text { familiar with organic } \\
\text { food production } \\
\text { Retailer has a good reputation } \\
\text { on the market } \\
\text { Retailer mostly } \\
\text { meets expectations } \\
\text { In some cases, it can happen } \\
\text { that the retailer does not keep } \\
\text { its promise, or it makes } \\
\text { false claims } \\
\text { They are not completely } \\
\text { satisfied with the price } \\
\text { Retailers do not know well } \\
\text { the specificities of organic } \\
\text { production and organic } \\
\text { products, and do not use } \\
\text { them enough in promotion } \\
\text { They are ready to sell to } \\
\text { alternative buyers }\end{array}$ & $\begin{array}{l}- \\
- \\
- \\
- \\
- \\
- \\
- \\
- \\
- \\
-\end{array}$ & $\begin{array}{l}\text { Retailer is reliable } \\
\text { Most of them are satisfied } \\
\text { with quality } \\
\text { of relationship } \\
\text { Retailers take into } \\
\text { consideration the interests } \\
\text { of both parties } \\
\text { Development of } \\
\text { professionalism of organic } \\
\text { food producers } \\
\text { We are loyal and } \\
\text { committed to the retailer } \\
\text { They are planning } \\
\text { future collaboration } \\
\text { Infrastructure development } \\
\text { is also crucial } \\
\text { The customer is ready to } \\
\text { help in collaboration } \\
\text { Problems are } \\
\text { solved promptly } \\
\text { They are dedicated to the } \\
\text { quality of relationships } \\
\text { and the collaboration with } \\
\text { the retailer }\end{array}$ & $\begin{array}{l}- \\
- \\
- \\
- \\
- \\
-\end{array}$ & $\begin{array}{l}\text { Quantity planning needs } \\
\text { to be worked on } \\
\text { Depending on the retailer, } \\
\text { commitment to organic } \\
\text { food products } \\
\text { and production } \\
\text { They are mostly loyal to } \\
\text { most retailers } \\
\text { Flexible relationships with } \\
\text { small retailers are based } \\
\text { on interpersonal trust } \\
\text { They are less committed to } \\
\text { the quality of the } \\
\text { relationship and } \\
\text { collaboration with } \\
\text { the customer }\end{array}$ \\
\hline $\begin{array}{l}\text { STRENGHTH/ADDICTION/ } \\
\text { OPPORTUNISM (domination, } \\
\text { bargaining power) }\end{array}$ & & $\begin{array}{l}\text { For retail chains, the amount } \\
\text { of production can affect } \\
\text { bargaining power } \\
\text { Dependence on retailers is } \\
\text { often conditioned by the } \\
\text { amount of production } \\
\text { The buyer has more } \\
\text { bargaining power in the } \\
\text { supply chain, but } \\
\text { not complete } \\
\text { The buyer not only follows } \\
\text { their interests, but respects } \\
\text { the tradition and belief in } \\
\text { the supplier }\end{array}$ & $\begin{array}{l}- \\
- \\
- \\
- \\
-\end{array}$ & $\begin{array}{l}\text { Quality products also } \\
\text { ensure greater } \\
\text { bargaining power } \\
\text { The retailer must } \\
\text { comply with the } \\
\text { retailer's contracts } \\
\text { Dependence on retailer is } \\
\text { often conditioned by the } \\
\text { type of product } \\
\text { It is not a contractually } \\
\text { dependent relationship }\end{array}$ & $\begin{array}{l}- \\
- \\
-\end{array}$ & $\begin{array}{l}\text { Smaller retailer does not } \\
\text { dominate so much, they } \\
\text { are more flexible } \\
\text { They are small and do not } \\
\text { have the power to } \\
\text { negotiate, but do not } \\
\text { depend on retailers } \\
\text { They would never rely } \\
\text { solely on selling through } \\
\text { a retailer }\end{array}$ \\
\hline
\end{tabular}


Table A1. Cont.

\begin{tabular}{|c|c|c|c|c|c|}
\hline \multirow[b]{2}{*}{ Metrics for Collaboration Items } & \multirow{2}{*}{$\begin{array}{c}\text { SIMILARITIES } \\
\text { 1st and 2nd Group of Organic } \\
\text { Food Producers }\end{array}$} & \multicolumn{4}{|c|}{ DIFFERENCES } \\
\hline & & & $\begin{array}{l}\text { 1st Group of Organic } \\
\text { Food Producers }\end{array}$ & & $\begin{array}{l}\text { 2nd Group of Organic } \\
\text { Food Producers }\end{array}$ \\
\hline $\begin{array}{l}\text { OVERALL PERFORMANCE } \\
\text { (business efficiency, individual } \\
\text { and entire chain performance, } \\
\text { support among chain members, } \\
\text { mutual benefits, } \\
\text { competitiveness.) }\end{array}$ & $\begin{array}{ll}\text { - } & \text { Collaboration and trust: } \\
\text { - } & \text { Significantly affected the } \\
\text { satisfaction of customers and } \\
\text { end consumers } \\
\text { - } \quad \text { Had very little effect on } \\
\text { improving the business } \\
\text { processes of producers } \\
\text { (collaboration } \\
\text { and optimization) } \\
\text { Did not significantly affect } \\
\text { the reduction of total costs } \\
\text { (e.g., logistics) of both parties } \\
\text { Did not significantly } \\
\text { affect flexibility }\end{array}$ & - & $\begin{array}{l}\text { Professionalism of the } \\
\text { organic food producer } \\
\text { Better production planning } \\
\text { Affects the expansion of } \\
\text { family farm } \\
\text { and employment } \\
\text { At retail chain level, } \\
\text { products of domestic } \\
\text { organic food producers are } \\
\text { poorly visible and } \\
\text { recognizable to consumers } \\
\text { Collaboration and trust } \\
\text { have significantly affected: } \\
\text { Improved communication } \\
\text { To reduce business risks } \\
\text { On optimization of the use } \\
\text { of resources in the supply } \\
\text { chain and optimize stocks } \\
\text { To reduce the opportunistic } \\
\text { behaviour of retailer } \\
\text { On demand planning } \\
\text { On the speed of } \\
\text { resolving complaints } \\
\text { On forming a lower price } \\
\text { than competitors } \\
\text { On the introduction } \\
\text { and/or improvement of } \\
\text { electronic commerce } \\
\text { Profit growth } \\
\text { Better competitive advantage } \\
\text { To improve } \\
\text { product quality } \\
\text { Collaboration and trust } \\
\text { did not significantly affect: } \\
\text { Reliability and speed } \\
\text { of delivery } \\
\text { Lead time }\end{array}$ & $\begin{array}{l}- \\
- \\
- \\
- \\
- \\
- \\
- \\
- \\
- \\
- \\
- \\
- \\
- \\
- \\
- \\
- \\
- \\
- \\
- \\
- \\
- \\
- \\
- \\
- \\
-\end{array}$ & 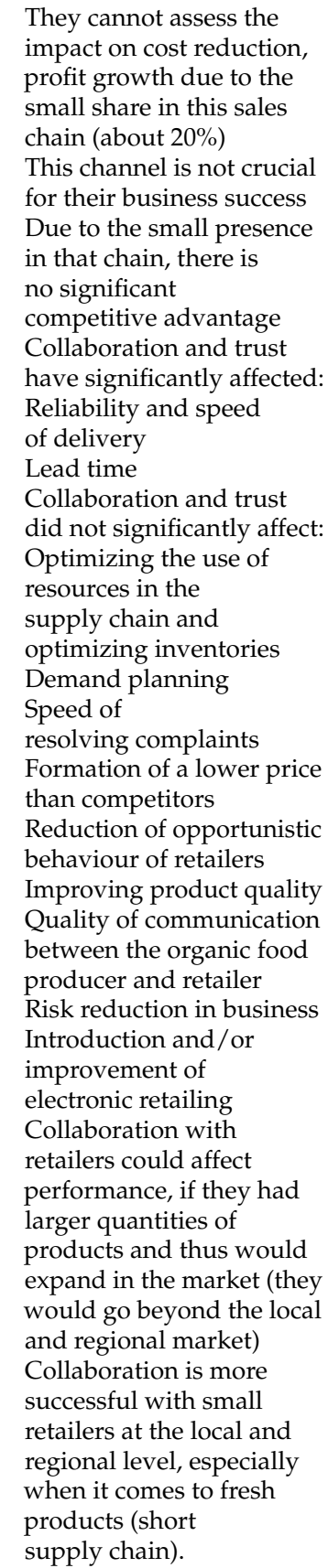 \\
\hline TRUST & 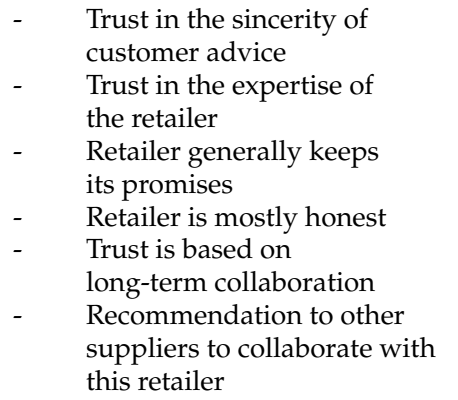 & - & $\begin{array}{l}\text { Trust in the information } \\
\text { and retail data } \\
\text { Due to the high integrity } \\
\text { in the supply chain } \\
\text { Retailer treats them fairly } \\
\text { and justly } \\
\text { Even in the case of } \\
\text { uncertain circumstances, } \\
\text { they will remain loyal to } \\
\text { their customers } \\
\text { They completely trust } \\
\text { their customer }\end{array}$ & $\begin{array}{l}- \\
- \\
- \\
- \\
-\end{array}$ & $\begin{array}{l}\text { They do not fully believe } \\
\text { in the information and } \\
\text { data that the retailer } \\
\text { shares with them } \\
\text { Retailer is generally fair } \\
\text { and honest } \\
\text { Problems can impair } \\
\text { customer loyalty } \\
\text { They partly trust } \\
\text { their customer }\end{array}$ \\
\hline
\end{tabular}




\section{References}

1. Rodale, M.; Schlosser, E. Organic Manifesto: How Organic Farming Can Heal Our Planet, Feed the World, and Keep Us Safe; Rodale Inc.: New York, NY, USA, 2011; ISBN 978-1-60961-136-1.

2. FiBL. The World of Organic Agriculture, Statistic \& Emerging Trends 2020. Available online: https://www.arc2020.eu/wpcontent/uploads/2020/03/organic-world-2020.pdf (accessed on 5 March 2021).

3. Cranfield, J.; Henson, S.; Holliday, J. The motives, benefits, and problems of conversion to organic production. Agric. Hum. Values 2009, 27, 291-306. [CrossRef]

4. Doernberg, A.; Zasada, I.; Bruszewska, K.; Skoczowski, B.; Piorr, A. Potentials and Limitations of Regional Organic Food Supply: A Qualitative Analysis of Two Food Chain Types in the Berlin Metropolitan Region. Sustainability 2016, 8, 1125. [CrossRef]

5. Gajdić, D.; Petljak, K.; Mesić, Ž. An exploration of distribution channels: Challenges and opportunities for organic food producers in Croatia. Èkon. Poljopr. 2018, 65, 1461-1482. [CrossRef]

6. Orsini, S.; Padel, S.; Gambelli, D.; Lernoud, J.; Sanders, J.; Solfanelli, F.; Stolze, M.; Willer, H.; Zanoli, R. Beyond “mainstream" and "alternative" in organic food supply chains: Empirical Examples of Added Value Distribution from Eight European Countries. Br. Food J. 2019, 122, 798-812. [CrossRef]

7. Boudahri, F.; Bennekrouf, M.; Belkaid, F.; Zaki, S. Reconfigurations of the Real Agri-foods Supply Chain with a Subcontractor to Accommodate Electronic Technology. In Advances in Mechanical and Electronic Engineering; Lecture Notes in Electrical Engineering; Jin, D., Lin, S., Eds.; Springer: Berlin/Heidelberg, Germany, 2012; Volume 177, pp. 551-556. ISBN 978-3-642-31515-2.

8. Fischer, C.; Hartmann, M. Introduction and Overview: Analysing Interorganizational Relationships in Agri-food Chains. In Agri-Food Chain Relationships; Fischer, C., Hartmann, M., Eds.; CAB International: Oxford, UK, 2010; pp. 11-21. ISBN 978-1-84593-642-6.

9. Dani, S. Food Supply Chain Management and Logistics: From Farm to Fork; Kogan Page: London, UK, 2015; ISBN 978-0-7494-7364-8.

10. Trienekens, J.H.; Wognum, P.M.; Beulens, A.J.M.; van der Vorst, J.G.A.J. Transparency in complex dynamic food supply chains. Adv. Eng. Inform. 2012, 26, 55-65. [CrossRef]

11. Martínez-Azúa, B.C.; López-Salazar, P.; Sama-Berrocal, C. Determining Factors of Innovative Performance: Case Studies in Extremaduran Agri-Food Companies. Sustainability 2020, 12, 9098. [CrossRef]

12. Seuring, S.; Müller, M. From a literature review to a conceptual framework for sustainable supply chain management. J. Clean. Prod. 2008, 16, 1699-1710. [CrossRef]

13. Elkington, J. Cannibals with Forks. The Triple Bottom Line of 21st Century Business; Capstone Publishing: Oxford, UK, 1997; ISBN 978-1-900961-27-1.

14. Fritz, M.; Schiefer, G. Food chain management for sustainable food system development: A European research agenda. Agribusiness 2008, 24, 440-452. [CrossRef]

15. Dania, W.A.P.; Xing, K.; Amer, Y. Collaboration behavioural factors for sustainable agri-food supply chains: A systematic review. J. Clean. Prod. 2018, 186, 851-864. [CrossRef]

16. Ambler-Edwards, S.; Bailey, K.S.; Kiff, A.; Lang, T.; Lee, R.; Marsden, T.; Simons, D.; Tibbs, H. Food Futures: Rethinking UK Strategy. A Chatham House Report UK; Chatham House: London, UK, 2009; ISBN 978-1-86203-211-8.

17. Giovannetti, E.; Bertolini, P.; Russo, M. Rights, Commons, and Social Capital: The Role of Cooperation in an Italian Agri-Food Supply Chain. Sustainability 2021, 13, 12161. [CrossRef]

18. Touboulic, A.; Walker, H. Love me, love me not: A nuanced view on collaboration in sustainable supply chains. J. Purch. Supply Manag. 2015, 21, 178-191. [CrossRef]

19. León-Bravo, V.; Caniato, F.; Caridi, M.; Johnsen, T. Collaboration for Sustainability in the Food Supply Chain: A Multi-Stage Study in Italy. Sustainability 2017, 9, 1253. [CrossRef]

20. Mesic, Željka; Molnár, A.; Cerjak, M. Assessment of traditional food supply chain performance using triadic approach: The role of relationships quality. Supply Chain Manag. Int. J. 2018, 23, 396-411. [CrossRef]

21. European Commission High Level Forum for a Better Functioning Food Supply Chain. Report, Brussels, 15 October 2014. Available online: https:/ / ec.europa.eu/commission/presscorner/detail/en/IP_14_1139 (accessed on 10 March 2021).

22. Kache, F.; Seuring, S. Linking collaboration and integration to risk and performance in supply chains via a review of literature reviews. Supply Chain Manag. Int. J. 2014, 19, 664-682. [CrossRef]

23. Lambert, D.M.; Cooper, M.C. Issues in Supply Chain Management. Ind. Mark. Manag. 2000, 29, 65-83. [CrossRef]

24. Mentzer, J.T.; Stank, T.P.; Esper, T.L. Supply chain management and its relationship to logistics, marketing, production, and operations management. J. Bus. Logist. 2008, 29,31-46. [CrossRef]

25. Sahay, B.S.; Maini, A. Supply chain: A shift from transactional to collaborative partnership. Decision 2002, $29,67-88$.

26. Benton, W.; Maloni, M. The influence of power driven buyer/seller relationships on supply chain satisfaction. J. Oper. Manag. 2004, 23, 1-22. [CrossRef]

27. Gellynck, X.; Kühne, B.; Weaver, R.D. Relationship Quality and Innovation Capacity of Chains: The Case of the Traditional Food Sector in the EU. Int. J. Food Syst. Dyn. 2011, 2, 1-22. [CrossRef]

28. Molnar, A.; Gellynck, X.; Weaver, R.D. Chain member perception of chain performance: The role of relationship quality. J. Chain Netw. Sci. 2010, 10, 27-49. [CrossRef]

29. Lobo, A.; Leckie, C.; Li, C. The impact of guanxi, xinyong and buyer collaboration on the loyalty and financial performance of vegetable farmers in China. Asia Pac. J. Mark. Logist. 2013, 25, 745-764. [CrossRef] 
30. Kühne, B.; Gellynck, X.; Weaver, R.D. The influence of relationship quality on the innovation capacity in traditional food chains. Supply Chain Manag. Int. J. 2013, 18, 52-65. [CrossRef]

31. Mathu, K.; Phetla, S. Supply chain collaboration and integration enhance the response of fast-moving consumer goods manufacturers and retailers to customer's requirements. S. Afr. J. Bus. Manag. 2018, 49, 8. [CrossRef]

32. De Búrca, S.; Voss, C. Supply chain relationship quality, the competitive environment and performance. Int. J. Prod. Res. 2005, 43, 3303-3320. [CrossRef]

33. Lambert, D.M. Supply Chain Management_Processes, Partnerships, Performance, 3rd ed.; Supply Chain Management Institute: Sarasota, FL, USA, 2008; p. 431.

34. Odongo, W.; Dora, M.; Molnár, A.; Ongeng, D.; Gellynck, X. Performance perceptions among food supply chain members: A Triadic Assessment of the Influence of Supply Chain Relationship Quality on Supply Chain Performance. Br. Food J. 2016, 118, 1783-1799. [CrossRef]

35. Razavi, S.M.; Abdi, M.; Amirnequiee, S.; Ghasemi, R. The impact of supply chain relationship quality and cooperative strategy on strategic purchasing. J. Logist. Manag. 2016, 5, 6-15. [CrossRef]

36. Crosby, L.A.; Evans, K.R.; Cowles, D. Relationship Quality in Services Selling: An Interpersonal Influence Perspective. J. Mark. 1990, 54, 68-81. [CrossRef]

37. Moorman, C.; Deshpande, R.; Zaltman, G. Factors Affecting Trust in Market Research Relationships. J. Mark. 1993, 57, 81. [CrossRef]

38. Ganesan, S. Determinants of Long-term Orientation in Buyer Seller Relationships. J. Mark. 1994, 58, 1-19. [CrossRef]

39. Geyskens, I.; Steenkamp, J.-B.E. Economic and social satisfaction: Measurement and relevance to marketing channel relationships. J. Retail. 2000, 76, 11-32. [CrossRef]

40. Lee, D.Y. Power, conflict and satisfaction in IJV supplier-Chinese distributor channels. J. Bus. Res. 2001, 52, 149-160. [CrossRef]

41. Hennig-Thurau, T.; Gwinner, K.P.; Gremler, D.D. Understanding Relationship Marketing Outcomes: An Integration of Rela-tional Benefits and Relationship Quality. J. Serv. Res. 2002, 4, 230-247. [CrossRef]

42. Sufiyan, M.; Haleem, A.; Khan, S.; Khan, M.I. Analysing Attributes of Food Supply Chain Management: A Comparative Study. In Lecture Notes in Mechanical Engineering; Springer: Singapore, 2019; pp. 515-523.

43. Batt, P.J. Building trust between growers and market agents. Supply Chain Manag. Int. J. 2003, 8, 65-78. [CrossRef]

44. Schulze-Ehlers, B.; Wocken, C.; Spiller, A. Relationship quality in agri-food chains: Supplier management in the German pork and dairy sector. J. Chain Netw. Sci. 2006, 6, 55-68. [CrossRef]

45. Zhang, X.; Hu, D. Farmer-buyer relationships in China: The effects of contracts, trust and market environment. China Agric. Econ. Rev. 2011, 3, 42-53. [CrossRef]

46. Boniface, B. Producer relationships segmentation in Malaysia's milk supply chains. Br. Food J. 2012, 114, 1501-1516. [CrossRef]

47. Chen, I.J.; Paulraj, A.; Lado, A.A. Strategic purchasing, supply management, and firm performance. J. Oper. Manag. 2004, 22, 505-523. [CrossRef]

48. Kottila, M.-R.; Rönni, P. Collaboration and trust in two organic food chains. Br. Food J. 2008, 110, 376-394. [CrossRef]

49. Kottila, M.-R. Knowledge sharing in organic food supply chains. J. Chain Netw. Sci. 2009, 9, 133-144. [CrossRef]

50. Boniface, B.; Gyau, A.; Stringer, R.; Umberger, W.J. Building Producer Loyalty in Malaysia's Fresh Milk Supply Chain. Aust. Agribus. Rev. 2010, 18, 1-29. [CrossRef]

51. Bezuidenhout, C.N.; Bodhanya, S.; Brenchley, L. An analysis of collaboration in a sugarcane production and processing supply chain. Br. Food J. 2012, 114, 880-895. [CrossRef]

52. Puspitawati, E.; Guyau, A.; Stringer, R.; Umberger, W.J.; Puspitawati, E.; Guyau, A.; Stringer, R.; Umberger, W.J. Determinants of Trust in the Indonesian Potato Industry: A Comparison Between Groups of Potato Farmers. J. Agribus. 2011, 29. [CrossRef]

53. Mutonyi, S.; Beukel, K.; Gyau, A.; Hjortsø, C. Price satisfaction and producer loyalty: The role of mediators in business to business relationships in Kenyan mango supply chain. Br. Food J. 2016, 118, 1067-1084. [CrossRef]

54. Bandara, S.; Leckie, C.; Lobo, A.; Hewege, C. Power and relationship quality in supply chains: The Case of the Australian Organic Fruit and Vegetable Industry. Asia Pac. J. Mark. Logist. 2017, 29, 501-518. [CrossRef]

55. Naspetti, S.; Lampkin, N.; Nicolas, P.; Stolze, M.; Zanoli, R. Organic Supply Chain Collaboration: A Case Study in Eight EU Countries. J. Food Prod. Mark. 2011, 17, 141-162. [CrossRef]

56. Thorsøe, M.H. Maintaining Trust and Credibility in a Continuously Evolving Organic Food System. J. Agric. Environ. Ethic. 2015, 28, 767-787. [CrossRef]

57. Aji, J.M.M. Exploring Farmer-supplier Relationships in the East Java Seed Potato Market. Agric. Agric. Sci. Procedia 2016, 9, 83-94. [CrossRef]

58. Sun, Y.; Liu, Z.; Yang, H. How Does Suppliers' Fairness Affect the Relationship Quality of Agricultural Product Supply Chains? J. Food Qual. 2018, 2018, 1-15. [CrossRef]

59. Burgess, K.; Singh, P.; Koroglu, R. Supply chain management: A structured literature review and implications for future research. Int. J. Oper. Prod. Manag. 2006, 26, 703-729. [CrossRef]

60. Sinha, P.R.; Whitman, L.; Malzahn, D. Methodology to mitigate supplier risk in an aerospace supply chain. Supply Chain Manag. Int. J. 2004, 9, 154-168. [CrossRef]

61. Barney, J. Firm Resources and Sustained Competitive Advantage. J. Manag. 1991, 17, 99-120. [CrossRef] 
62. Wilding, R.; Humphries, A.S. Understanding collaborative supply chain relationships through the application of the Williamson organisational failure framework. Int. J. Phys. Distrib. Logist. Manag. 2006, 36, 309-329. [CrossRef]

63. Patterson, P.G.; Johnson, L.W.; Spreng, L.W. Modelling the Determinants of Customer Satisfaction for Business-to-Business Professional Services. J. Acad. Mark. Sci. 1997, 25, 4-17. [CrossRef]

64. Anderson, J.C.; Narus, J.A. A Model of Distributor Firm and Manufacturer Firm Working Partnerships. J. Mark. 1990, 54, 42. [CrossRef]

65. Morgan, R.M.; Hunt, S.D. The Commitment-Trust Theory of Relationship Marketing. J. Mark. 1994, 58, 20. [CrossRef]

66. Geyskens, I.; Steenkamp, J.-B.E.; Scheer, L.; Kumar, N. The effects of trust and interdependence on relationship commitment: A trans-Atlantic study. Int. J. Res. Mark. 1996, 13, 303-317. [CrossRef]

67. Zander, K.; Beske, P. Happy Growers! Relationship Quality in the German Organic Apple Chain. Int. Food Agribus. Manag. 2014, 17, 1-20. [CrossRef]

68. Wu, I.-L.; Chuang, C.-H.; Hsu, C.-H. Information sharing and collaborative behaviors in enabling supply chain performance: A social exchange perspective. Int. J. Prod. Econ. 2014, 148, 122-132. [CrossRef]

69. Capaldo, A.; Giannoccaro, I. Interdependence and network-level trust in supply chain networks: A computational study. Ind. Mark. Manag. 2015, 44, 180-195. [CrossRef]

70. Hobbs, J.E. A transaction cost approach to supply chain management. Supply Chain Manag. Int. J. 1996, 1, 15-27. [CrossRef]

71. Jamaluddin, F.; Saibani, N. Systematic Literature Review of Supply Chain Relationship Approaches amongst Business-to-Business Partners. Sustainability 2021, 13, 11935. [CrossRef]

72. Fischer, C.; Gonzalez, M.A.; Henchion, M.; Leat, P. Trust and economic relationships in selected European agrifood chains. Food Econ. Acta Agric. Scand. Sect. C 2007, 4, 40-48. [CrossRef]

73. Lu, H.; Feng, S.; Trienekens, J.H.; Omta, S. Network strength, transaction-specific investments, inter-personal trust, and relationship satisfaction in Chinese agri-food SMEs. China Agric. Econ. Rev. 2012, 4, 363-378. [CrossRef]

74. Doney, P.M.; Cannon, J.P. An Examination of the Nature of Trust in Buyer-Seller Relationships. J. Mark. 1997, 61, 35-51. [CrossRef]

75. Viitaharju, L.; Lähdesmäki, M. Antecedents of trust in asymmetrical business relationships: Differing Perceptions between Food Producers and Retailers. Mark. Intell. Plan. 2012, 30, 567-587. [CrossRef]

76. Ding, M.J.; Jie, F.; Parton, K.A.; Matanda, M.J. Relationships between quality of information sharing and supply chain food quality in the Australian beef processing industry. Int. J. Logist. Manag. 2014, 25, 85-108. [CrossRef]

77. Fritz, M.; Fischer, C. The Role of Trust in European Food Chains: Theory and Empirical Findings. Int. Food Agribus. Manag. 2007, 10, 1-24. [CrossRef]

78. Aramyan, L.H.; Lansink, A.O.; Van Der Vorst, J.G.A.J.; Van Kooten, O. Performance measurement in agri-food supply chains: A case study. Supply Chain Manag. Int. J. 2007, 12, 304-315. [CrossRef]

79. Ministry of Agriculture of the Republic of Croatia. Available online: https:// poljoprivreda.gov.hr/statistika-360/360 (accessed on 20 April 2021).

80. Grahovac, P. Ekonomika Poljoprivrede; Golden Marketing-Tehnička Knjiga: Zagreb, Croatia, 2005; ISBN 953-212-247-8.

81. Petljak, K. Distribution Channels of Organic Food in the Republic of Croatia; Poslovna Izvrsnost: Zagreb, Croatia, 2013; Volume 7, pp. 73-97.

82. Šugar, T.; Brščić, K.; Zaborski, T.K. Mišljenje proizvođača ekoloških prehrambenih proizvoda o mogućnostima razvoja ekološke poljoprivrede u Hrvatskoj. Zb. Veleučilišta Rijeci 2020, 8, 455-469. [CrossRef]

83. Essoussi, L.H.; Zahaf, M. Decision making process of community organic food consumers: An exploratory study. J. Consum. Mark. 2008, 25, 95-104. [CrossRef]

84. Chiffoleau, Y.; Dourian, T. Sustainable Food Supply Chains: Is Shortening the Answer? A Literature Review for a Research and Innovation Agenda. Sustainability 2020, 12, 9831. [CrossRef]

85. Kosior, K. Digital transformation in the agri-food sector-opportunities and challenges. Roczniki Ann. 2018, 2, 98-104. [CrossRef]

86. Jorge-Vázquez, J.; Chivite-Cebolla, M.; Salinas-Ramos, F. The Digitalization of the European Agri-Food Cooperative Sector. Determining Factors to Embrace Information and Communication Technologies. Agriculture 2021, 11, 514. [CrossRef]

87. Zhu, Z.; Bai, Y.; Dai, W.; Liu, D.; Hu, Y. Quality of e-commerce agricultural products and the safety of the ecological environment of the origin based on 5G Internet of Things technology. Environ. Technol. Innov. 2021, 22, 101462. [CrossRef]

88. Mozas-Moral, A.; Fernández-Uclés, D.; Bernal-Jurado, E.; Medina-Viruel, M.J. Web quality as a determining factor in the online retailing of organic products in Spain. New Medit. 2016, 15, 28-36.

89. Hamzaoui-Essoussi, L.; Sirieix, L.; Zahaf, M. Trust orientations in the organic food distribution channels: A comparative study of the Canadian and French markets. J. Retail. Consum. Serv. 2013, 20, 292-301. [CrossRef]

90. Hingley, M.; Lindgreen, A.; Casswell, B. Supplier-Retailer Relationships in the UK Fresh Produce Supply Chain. J. Int. Food Agribus. Mark. 2006, 18, 49-86. [CrossRef]

91. Dibb, S.; Ferrell, O.C.; Pride, W.M.; Simkin, L. Marketing Concepts and Strategies, 3rd ed.; Houghton Mifflin: Boston, MA, USA, 1997; ISBN 1-900961-27-X.

92. Patton, M.Q. How to Use Qualitative Methods in Evaluation; Program Evaluation, 2nd ed.; Sage Publications: London, UK, 1987; ISBN 978-0-8039-3129-9.

93. Uddin, N. Inter-organizational relational mechanism on firm performance: The Case of Australian Agri-Food. Ind. Manag. Data Syst. 2017, 117, 1934-1953. [CrossRef] 
94. Corbin, J.; Strauss, A. Basics of Qualitative Research: Techniques and Procedures for Developing Grounded Theory, 3rd ed.; Sage: Thousand Oaks, CA, USA, 2008. [CrossRef]

95. Mazurek-Kusiak, A.; Sawicki, B.; Kobyłka, A. Contemporary Challenges to the Organic Farming: A Polish and Hungarian Case Study. Sustainability 2021, 13, 8005. [CrossRef]

96. Amentae, T.K.; Gebresenbet, G.; Ljungberg, D. Examining the interface between supply chain governance structure choice and supply chain performances of dairy chains in Ethiopia. Int. Food Agribus. Manag. Rev. 2018, 21, 1061-1081. [CrossRef]

97. Sahara, S.; Gyau, A. Contractual arrangements and commitment in the Indonesian supermarket channel. Br. Food J. 2014, 116, 765-779. [CrossRef]

98. Hamm, U.; Gronefeld, F. The European Market for Organic Food: Revised and Updated Analysis; School of Management and Business, University of Wales: Aberystwyth, UK, 2004; ISBN 0954327947.

99. Padel, S.; Midmore, P. The development of the European market for organic products: Insights from a Delphi study. Br. Food J. 2005, 107, 626-646. [CrossRef]

100. Fischer, C. Trust and communication in European agri-food chains. Supply Chain Manag. Int. J. 2013, 18, 208-218. [CrossRef]

101. Anastasiadis, F.; Poole., N. Emergent supply chains in the agrifood sector: Insights from a whole chain approach. Supply Chain. Manag. 2015, 20, 353-368. [CrossRef]

102. Lu, H.; Trienekens, J.H.; Omta, S.W.F. Does guanxi matter for vegetable supply chain in China? A case study approach. In International Agri-Food Chains and Networks: Management and Organizations; Bijman, J., Ed.; Wageningen Academic: Wageningen, The Netherlands, 2006; pp. 31-47. ISBN 978-90-76998-95-4.

103. Callado, A.A.C.; Jack, L. Relations between usage patterns of performance indicators and the role of individual firms in fresh fruit agri-food supply chains. J. Appl. Account. Res. 2017, 18, 375-398. [CrossRef]

104. Selnes, F. Antecedents and consequences of trust and satisfaction in buyer-seller relationships. Eur. J. Mark. 1998, 32, 305-322. [CrossRef]

105. Hogarth-Scott, S. Retailer-supplier partnerships: Hostages to fortune or the way forward for the millennium? Br. Food J. 1999, 101, 668-682. [CrossRef]

106. Dapiran, G.P.; Hogarth-Scott, S. Are co-operation and trust being confused with power? An analysis of food retailing in Australia and the UK. Int. J. Retail. Distrib. Manag. 2003, 31, 256-267. [CrossRef]

107. Lindgreen, A.; Palmer, R.; Trienekens, J. Relationships within the supply chain: A case study. J. Chain Netw. Sci. 2005, 5, 85-99. [CrossRef]

108. Batt, P.J.; Rexha, N. Building Trust in Agribusiness Supply Chains. J. Int. Food Agribus. Mark. 2000, 11, 1-17. [CrossRef]

109. Zhang, M.; Huo, B. The impact of dependence and trust on supply chain integration. Int. J. Phys. Distrib. Logist. Manag. 2013, 43, 544-563. [CrossRef]

110. Malagueño, R.; Golgeci, I.; Fearne, A. Customer categorization, relational justice and SME performance in supermarket supply chains. Supply Chain Manag. Int. J. 2019, 24, 417-429. [CrossRef]

111. Singh, H.; Garg, R.K.; Sachdeva, A. Supply chain collaboration: A state-of-the-art literature review. Uncertain Supply Chain Manag. 2018, 6, 149-180. [CrossRef]

112. Jie, F.; Parton, K.A.; Cox, R.J. Linking supply chain practices to competitive advantage. Br. Food J. 2013, 115, 1003-1024. [CrossRef] 